\title{
BMJ Open Bibliometric analysis of the top-cited gastroenterology and hepatology articles
}

\author{
Samy A Azer, ${ }^{1}$ Sarah Azer ${ }^{2}$
}

To cite: Azer SA, Azer S. Bibliometric analysis of the top-cited gastroenterology and hepatology articles. BMJ Open 2016:6:e009889. doi:10.1136/bmjopen-2015009889

- Prepublication history and additional material is available. To view please visit the journal (http://dx.doi.org/ 10.1136/bmjopen-2015009889).

Received 1 September 2015 Accepted 18 December 2015

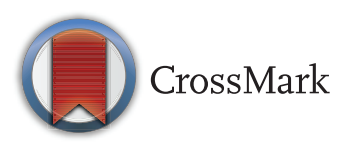

${ }^{1}$ Department of Medical Education and the Curriculum Development and Research Unit, College of Medicine, King Saud University, Riyadh, Saudi Arabia

${ }^{2}$ Austin Hospital, University of Melbourne, Melbourne, Victoria, Australia

Correspondence to Professor Samy A Azer; azer2000@optusnet.com.au

\section{ABSTRACT}

Objective: To identify the top-cited articles in gastroenterology and hepatology, and analyse their characteristics.

Methods: Two searches were conducted in the Science Citation Index Expanded database; a search of 69 journals under the category 'Gastroenterology and Hepatology' (list A) and a keyword search of all journals (list B). The search results were analysed and the inter-rater coefficient of agreement between evaluators was measured using Cohen $\kappa$.

Results: The number of citations varied from 1049 to 2959 in list A and from 1929 to 5500 in list B. In both lists, the majority of articles were research papers. No significant correlations were found between the number of citations and the number of years since publication $\left(R^{2}=0.00992, p=0.473\right.$ and $R^{2}=0.00202$, $p=0.757$, respectively). However, the mean number of citations of papers published before the year 2000 was lower than those published after $2000(36.70 \pm 19.31$ vs $106.03 \pm 39.22)$. No correlation was found between number of authors and the number of citations $\left(R^{2}=0.04352, p=0.130\right)$, but strong correlations were found between the number of institutes involved or number of countries and the number of citations $\left(R^{2}=0.275, p<0.001\right.$ and $R^{2}=0.16181, p=0.003$, respectively). Females were under-represented in authorship (45 vs 254, $\mathrm{p}=0.004$ ). Only 21 papers (of 54 ) in list A were supported by grants. No correlation was found between number of grants received and the number of citations $\left(R^{2}=0.02573, p=0.247\right)$. The interrater agreement between evaluators had a Cohen $\kappa$ coefficient $0.76-0.84$.

Conclusions: Top-cited articles were not only published in highly ranked journals specialising in Gastroenterology and Hepatology but also in 14 journals not specialised in this field. The number of citations correlated with the number of institutes and the number of countries involved but not with the number of grants received or the number of authors. Females were under-represented in the authorship.

\section{INTRODUCTION}

While the number of citations alone cannot reveal why a paper is considered important enough to attract citations by other researchers ${ }^{1}$ nor reflect fully the quality of a paper, ${ }^{2}$ the citations received by scientific publications have been used as a proxy

\section{Strengths and limitations of this study}

- Two searches were conducted in the Science Citation Index Expanded database.

- The search was based on journals with high impact factor and only those in the English language.

- Analysis explored a range of parameters in the assessment.

measurement to assess the work of researchers and impact of research, ${ }^{3}$ and to rank researchers on the basis of differences in citation indices. ${ }^{3} 4$ Recently, Nicholson and Ioannidis ${ }^{5}$ explored whether there is a link between highly cited research and US National Institute of Health (NIH) funding. Their findings showed that too many US authors of the most innovative and influential papers in the life sciences do not receive NIH funding. ${ }^{5}$ While these findings raise a number of possibilities, there is ongoing debate on the importance of citations received by scientific publications. ${ }^{6}$ For example, using citation metrics to appraise scientists and their work has many pitfalls, ${ }^{7}$ yet the numbers of published research papers and their citations have been used as a measure to assess the quality of research on national scales and to set it in an international context. ${ }^{8}$ This may explain why topcited publications are usually seen by researchers and universities as influential papers, and can be used in measuring the impact of the work of other researchers. ${ }^{9}$

The reputation of scientists and the influence of their work in a particular discipline can therefore be proportionally related to the number of citations received by their publications. ${ }^{3}$ This is particularly important when there is a pattern of consistency and progressive input into their discipline over time, as demonstrated from their publications' record and the citation history of their publications. The more influential their papers, the more they are making an impact, not only in their institutes or at a national level, but at a global level as well. ${ }^{5}$ 
The identification of top-cited articles in gastroenterology and hepatology is useful for a number of reasons. First, the search identifies the articles that have contributed to the different topics related to the discipline. Furthermore, the top-cited articles enable readers to know authors who and institutions that have contributed to such work. Garfield and Welljams-Dorof ${ }^{10}$ showed that a simple, quantitative and objective algorithm based on citation data of high-impact research authors, can effectively corroborate and even help in predicting Nobel Prize award winners. Finally, the lists present useful information to authors and researchers regarding top-cited articles that can be used in teaching and learning of undergraduate and postgraduate students. ${ }^{11}$

Top-cited papers have been recently studied in several fields, including cardiovascular medicine, ${ }^{11}$ cardiac surgery, ${ }^{12}$ arthroscopic orthopaedic surgery, ${ }^{13}$ respiratory system, ${ }^{14}$ dermatology ${ }^{15}$ and medical education. ${ }^{16}$ An abstract on the top-cited articles in gastroenterology and hepatology was presented at Asia-Pacific Digestive Week in 2009. ${ }^{17}$ The objectives of this study are to identify the 50 top-cited articles in gastroenterology and hepatology, and to analyse their characteristics.

\section{METHODS}

\section{Study design}

The Science Citation Index Expanded (SCI-Expanded) database of the Thomson Reuters Web of Science was used for citation tracking and the identification of mostcited articles. Although Scopus and Google scholar also provide citation tracking, it was decided to limit the search to the SCI-Expanded database. This is because the SCI-Expanded database is regularly updated and its 2014 Journal Citation Reports (JCRs) included 76 journals in the field of Gastroenterology and Hepatology. Google Scholar was not used because it is difficult to search and its citations include textbooks, monographs, conference proceedings, as well as non-peer-reviewed work. ${ }^{18}$ The Scopus database was not searched because it is not extensive in its coverage and its records only go back to $1966 .{ }^{19}$

To maximise the outcomes of this study, two search strategies were used. The first aimed at searching journals listed in the JCR 2014 under the category 'Gastroenterology and Hepatology'. The second search aimed at identifying most frequently cited articles in all the database including journals not dedicated to gastroenterology and hepatology, such as general medicine, internal medicine and general surgery journals, as well as biology and related disciplines.

\section{Searching the gastroenterology and hepatology journals}

On 27 May 2015, the two authors (a professor of medical education as well as gastroenterology consultant, and a senior surgical registrar) along with a research assistant with a background in medicine, searched the SCI-Expanded database to retrieve topcited articles. This search was conducted via the JCR 2014 under the category 'Gastroenterology and Hepatology'. The category comprised 76 journals at the time of conducting the search. Seven journals were not searched because they were in languages other than English. Journals not in the English language were excluded because neither of the authors of this work are competent in the Spanish, Italian or German languages. Also, there are articles on the topic covering top-cited articles in languages other than English. ${ }^{20}$ Interestingly, after identifying the list of top-cited articles, and again checking these seven non-English journals, none had a paper with a citation higher than the paper ranked number 50 in the list.

A list identifying the 50 top-cited articles was reviewed again and checked regarding authorship, title of the article, number of citations and the institution of the first author (list A, see appendix 1). Articles that shared the same number of citations were given the same rank number.

\section{Searching the Web of Science using keywords}

The second search was conducted on 27 May 2015. The aim of the second search was to identify top-cited articles published in journals not dedicated to the field. The SCI-Expanded database was searched using the following keywords: 'Bilirubin', 'Biliary disease', 'Esophageal disorder', 'Esophageal reflux disease', 'Esophageal cancer', 'Peptic ulcer disease', 'Helicobacter pylori', 'Gastric ulcer', 'Gastritis', 'Gastric cancer', 'Pancreatitis', 'Pancreatic cancer', 'Jaundice', 'Malabsorption', 'Celiac disease', 'Irritable bowel syndrome', 'Inflammatory bowel disease', 'Ulcerative colitis', 'Crohn's disease', 'Colitis', 'Diarrhea', 'Constipation', 'Esophageal varices', 'Chronic hepatitis', 'Viral hepatitis', 'Cirrhosis', 'Ascites', 'Chronic liver disease', 'Liver cell failure', 'End-stage liver disease', 'Gastrointestinal bleeding', 'Colon cancer', 'Diverticular disease', 'Liver function', 'Gallbladder disease', 'Gallstones', 'Cholecystitis', 'Medications and gastrointestinal diseases', 'Vomiting', 'Abdominal pain', 'Liver transplantation'; and 'Gastrointestinal endoscopy', 'Gastrointestinal disease', 'gastrointestinal motility', 'Liver disease'.

These keywords were identified using the terminology used by major journals in gastroenterology and hepatology, and the major conference proceedings in the field such as the American Gastroenterological Association Annual Scientific Meeting, the American College of Gastroenterology Annual Scientific Meeting, the United European Gastroenterology Week, the Canadian Digestive Diseases Week, World Gastroenterology Congress and the American Association for the Study of Liver Diseases Annual Meeting.

\section{Inclusion and exclusion criteria}

Papers focusing on gastroenterology or hepatology as the main topic and in the English language were 
included. The exclusion criteria were: (1) articles in languages other than English, (2) articles focused on broad areas without giving the whole emphasis to gastroenterology or hepatology knowledge.

\section{Assessing the articles}

Following the methods of Lefaivre $e t a l^{21}$ each paper in the top 50 most cited articles list was reviewed. The full text of the articles included in lists A and B was obtained and a copy given to each evaluator. The following information was analysed: (1) the authors' names and affiliations, (2) the city and country of publication, (3) the number of citations and (4) the year of publication and the calculation of the number of years since publication.

It was decided not to use the Web of Science classification because we noted that papers identified by the publishing journals as original research, article or practical guidelines were all grouped by the Web of Science and identified under the category 'article' or 'review'. For consistency and for the purposes of this research, a definition of the category 'review paper', 'article', 'educational guide' and 'research' has been given in the glossary (box 1). Also, the type of research used in the top-cited papers has been placed under the following types: cross-sectional, case-control, cohort study, randomised controlled trial, experimental study and causalcomparative study. A definition of each type has been given in the glossary (box 1). The two authors independently ranked each paper identified with regard to paper category and research type for research papers. Articles that covered more than one topic were classified on the basis of the aim of the study and the main outcome. These articles were discussed among the researchers until a final topic was identified.

The number of authors for each publication and the representation of females in the authorship of top-cited articles were identified. Collaboration type was determined by the addresses of the authors, and the term 'country independent work' was assigned if the researchers' addresses were from the same country. Articles that were the result of collaborative work from more than one country were identified. ${ }^{22}$ Those from the same country were classified into those from one institute and those from more than one institute. ${ }^{23}$ Papers that received grant support were also identified.

\section{Evaluating the journals}

The journals in which the top 50 articles were published were evaluated with respect to the following: (1) the Impact Factor of each journal, determined as reported in the JCR 2014 and (2) the ranking of the article, at the time of the research, in comparison to other articles published in that journal on the basis of the number of citations obtained. For example, an article ranked number 1 in the journal it was published in means that the article received the highest number of citations in comparison to all other articles published in that journal. The aim of this evaluation was to assess the position of articles identified among the 50 top-cited articles in regard to their ranking among other articles published in their respective journals. Such assessment will give a better idea about the significance of the articles included in list B among other topics published in journals not dedicated to the field.

\section{Statistical analysis}

Using SPSS software (IBM SPSS Statistics Premium V.22.0 for Mac OS-SPSS Inc, Chicago, Illinois, USA), the data were analysed and reported as total and percentage. Pearson's correlation coefficient $(r)$ was calculated to determine if the number of years since publication was correlated to the number of citations obtained. Also, the correlations between the number of authors, the number of institutes or the number of countries involved or the number of grants received against the number of citations were calculated. The degree of agreement between evaluators was calculated using Cohen $\kappa$ index for inter-rater coefficient. ${ }^{24}$

\section{RESULTS}

\section{Top-cited papers identified by searching journals (list A)}

Appendix 1 summarises the characteristics of top-cited articles published in the gastroenterology and hepatology journals (list A) ${ }^{25-78}$ Articles are listed in descending order from 1 to 50 , with the highest absolute citation number ranked 1 and the article with the lowest citation ranked 50, as on the day of the search. Articles with the same number of citations were given the same rank number. Four articles ${ }^{49} 56 \quad 6478$ had the same number of citations and were given the same ranks. Therefore, the total number of articles in list A is 54, and not 50. The denominator used in calculating the percentages is 54. All articles were published in the English language (list A).

Table 1 shows that these articles were published over a 66-year period (from 1945 to 2011). During the period from 1945 to 1987 , only seven articles $(12.9 \%)$ were included. However, the number increased progressively from 1988 to 2011, making a total of 47 (87\%) articles.

Table 2 summarises the distribution of gastroenterology and hepatology topics in relation to the four categories. The majority of the top-cited articles were research papers $(\mathrm{n}=24,44.4 \%)$, the remaining were practical guidelines $(\mathrm{n}=12,22.2 \%)$ and reviews $(\mathrm{n}=12$, $22.2 \%)$. Only six were articles $(11.1 \%)$. The topics can be summarised as follows: chronic hepatitis and viral hepatitis $(\mathrm{n}=12,22.2 \%)$, hepatocellular carcinoma $(\mathrm{n}=9$, $16.7 \%)$, inflammatory bowel disease $(n=7,12.9 \%)$, colorectal cancer $(n=7,12.9 \%)$, fatty liver disease $(n=6$, $11.1 \%)$, gastro-oesophageal reflux disease $(n=2,3.7 \%)$, gastric ulcer and $H$. pylori $(\mathrm{n}=2,3.7 \%)$, prostaglandins and gastric protection $(\mathrm{n}=2,3.7 \%)$, and end-stage liver disease and liver failure $(n=2,3.7 \%)$. The remaining topics are shown in table 2. 
Box 1 Glossary

Articles: Reports with conclusions that represent a substantial advance in the understanding of an important topic or problem. They provoke thoughts and ideas, and they aim at establishing new directions.

Case-control studies: In these studies, patients who developed a disease are compared with controls or referents groups (with no disease). The studies aim at estimating ORs or changes caused by the disease. The researchers have to identify potential confounding factors by making appropriate adjustment in the design of the study and in the analysis. This may be achieved either by matching cases and controls for exposure to confounders on an individual basis (by pairing each case with a control of same age and sex) or group comparison basis (controls have overall age and sex distribution similar to the patients).

Causal-comparative studies: These studies attempt to identify cause-effect relationships. The approach involves starting with an effect and seeking possible causes. The design involves comparison.

Cohort studies: In these studies, a group of individuals is followed over a period of time to assess the individuals' health outcomes. In these studies, individuals who do not have the outcome of interest initially are identified and grouped in subsets that differ in their exposure to a particular factor, for example, hepatitis C infection, and non-exposure. The follow-up of the two groups over time enables the comparison of health outcomes. The cohort could be grouped according to whether they had or had not been exposed and the analysis of health outcomes could compare the frequency (the incidence) of a particular change (eg, liver cirrhosis) between the groups. Cohort studies could be prospective cohort studies or retrospective cohort studies.

Cross-sectional studies: These studies measure, in a population, at a point in time, the prevalence of health outcomes or determinants of health or both. They can also be used in planning healthcare. Cross-sectional studies are best suited to study aetiology of diseases that produce little disability in a population or the early phase of more serious diseases. However, the results of cross-sectional surveys (design) that explore aetiology have to be interpreted with great caution, as the findings identified may be associated changes rather than the causes of the change or the condition.

Experimental studies: In these studies, researchers are in control of the research design by determining the groups to be exposed and the groups not to be exposed. However, deliberate exposure of participants to potentially serious hazards does not follow the World Medical Association's Declaration of Helsinki, will not be approved by a formally constituted research ethics committee and may form a constraint on such research. In animal work, experimental study design may be in vivo or in vitro studies.

Practical guidelines: Resources usually written by a team of experts in the area/topic, and aimed at providing clinicians and researchers with a resource on principles, current evidence, applications and regulations.

Randomised controlled trials: Aim at evaluating therapeutic intervention by using experimental design and randomisation of participants. Participants are selected on the basis of inclusion criteria; those satisfying the entry criteria and representing the target population are asked to consent to participation. Participants are randomised to the intervention (treatment) under comparison using a valid randomisation method, usually conducted by a third party, such as web-based or phone-based randomisation. The use of randomisation means eventual distribution of any confounding factors and prognostic markers between the different treatment groups.

Reviews: Articles reviewing progress of knowledge in a particular topic, critically analysing the current status of the literature and presenting an understanding of the topic by discussing related literature, and identifying gaps in knowledge and highlighting future directions for further research.

Research papers: Original studies making systematic investigations into a problem, using valid and reliable methods in order to establish answers to the research questions made, and come with conclusions. Research methods used may be qualitative, quantitative or mixed methods.

The articles were published in the following journals: Gastroenterology ( $\mathrm{n}=26,48 \%)$, Hepatology ( $\mathrm{n}=17,31.4 \%)$, Journal of Hepatology $(\mathrm{n}=2,3.7 \%)$, American Journal of
Gastroenterology $(\mathrm{n}=2,3.7 \%)$, Gut $(\mathrm{n}=2,3.7 \%)$, Seminars in Liver Disease ( $\mathrm{n}=1,1.8 \%)$, Gastrointestinal Endoscopy $(\mathrm{n}=1,1.8 \%)$, Diseases of Colon E Rectum $(\mathrm{n}=1,1.8 \%)$,

Table 1 Top-cited articles in Gastroenterology and Hepatology, identified by searching gastroenterology and hepatology journals (list A): by article type and year of publication*

\begin{tabular}{|c|c|c|c|c|c|c|c|c|}
\hline \multirow[b]{2}{*}{$\begin{array}{l}\text { Article } \\
\text { type }\end{array}$} & \multicolumn{8}{|c|}{ Year of publication: number of articles (references) } \\
\hline & 1945-1975 & $1976-1981$ & 1982-1987 & 1988-1993 & 1994-1999 & 2000-2005 & 2006-2011 & $\begin{array}{l}\text { Total } \\
(\%)\end{array}$ \\
\hline Article & & $1^{74}$ & & $2^{4953}$ & $2^{2735}$ & $1^{28}$ & & $6(11.1)$ \\
\hline Review & & & & $1^{43}$ & $4^{31384663}$ & $\begin{array}{l}5^{526467} \\
7576\end{array}$ & $2^{32} 77$ & 12 (22.2) \\
\hline Practical & & & & & $2^{4755}$ & $3^{255059}$ & $7^{39-414466} 6970$ & $12(22.2)$ \\
\hline Research & $1^{45}$ & $4^{26293765}$ & $1^{61}$ & $5^{5156606871}$ & $4^{33} 364257$ & $\begin{array}{l}8^{30} 344858 \\
62727378\end{array}$ & $1^{54}$ & $24(44.4)$ \\
\hline Total (\%) & $1(1.8)$ & $5(9.2)$ & $1(1.8)$ & $8(14.8)$ & $12(22.2)$ & $17(31.5)$ & $10(18.5)$ & $54(100)$ \\
\hline
\end{tabular}

${ }^{*}$ The search was conducted on 27 May 2015. The total number of articles included in list $A$ is 54 , and not 50 , because 4 articles had the same number of citations. Articles with reference numbers ${ }^{25-33}$ appeared in lists $A$ and $B$, but with different rankings. 
Table 2 Top-cited articles in Gastroenterology and Hepatology, identified by searching gastroenterology and hepatology journals (list $A$ ): by article topic and category*

\begin{tabular}{|c|c|c|c|c|c|}
\hline \multirow[b]{2}{*}{ Topic† } & \multicolumn{5}{|c|}{ Category: number of articles (references) } \\
\hline & Article & Review & Practical guidelines & Research & Total $(\%)$ \\
\hline Gastro-oesophageal reflux disease & & & $1^{69}$ & $1^{57}$ & $2(3.7)$ \\
\hline Gastric ulcer, Helicobacter pylori & & & $1^{70}$ & $1^{45}$ & $2(3.7)$ \\
\hline Prostaglandins and gastric protection & $1^{74}$ & & & $1^{37}$ & $2(3.7)$ \\
\hline Functional bowel disease & & & $1^{40}$ & $1^{56}$ & $2(3.7)$ \\
\hline Coeliac disease & $1^{53}$ & & & & $1(1.8)$ \\
\hline Intestinal ischaemia & & & & $1^{65}$ & $1(1.8)$ \\
\hline Inflammatory bowel disease & & $3^{466777}$ & & $4^{29606168}$ & $7(12.9)$ \\
\hline Colorectal cancer & $1^{49}$ & $1^{75}$ & $3^{475055}$ & $2^{3351}$ & 7 (12.9) \\
\hline Chronic hepatitis and viral hepatitis & $1^{27}$ & $2^{3164}$ & $4^{41445966}$ & $5^{2636587378}$ & $12(22.2)$ \\
\hline Fatty liver disease & $1^{35}$ & $1^{38}$ & & $4^{30424862}$ & $6(11.1)$ \\
\hline End-stage liver disease and liver failure & & & & $2^{3471}$ & $2(3.7)$ \\
\hline Hepatocellular carcinoma & $1^{28}$ & $4^{32527663}$ & $2^{2539}$ & $2^{5472}$ & $9(16.7)$ \\
\hline Endoscopic sphincterotomy & & $1^{33}$ & & & $1(1.8)$ \\
\hline Total (\%) & $6(11.1)$ & $12(22.2)$ & $12(22.2)$ & $24(44.4)$ & $54(100)$ \\
\hline
\end{tabular}

Digestive Diseases and Sciences $(\mathrm{n}=1,1.8 \%)$ and Journal of Viral Hepatitis $(\mathrm{n}=1,1.8 \%)$ (see online supplementary appendix 1).

The most frequently cited article, by Bruix and Sherman (2005), was cited 2959 times over 10 years. $^{25}$ Two articles were ranked number 50; an article by Baggio and Drucker ${ }^{77}$ was cited 1049 times over 8 years, and an article by Bedossa $e t a l^{78}$ cited 1049 times over 12 years. No correlation was found between the number of citations of these papers and the number of years since publication $\left(\mathrm{R}^{2}=0.00992, \mathrm{p}=0.473\right)$ (figure $\left.1 \mathrm{~A}\right)$. However, the mean number of citations of papers published before 2000 was lower than those published after $2000(36.70 \pm 19.31$ vs $106.03 \pm 39.22)$ (figure $1 \mathrm{~B}, \mathrm{C}$ ).

A strong correlation was found between the number of institutes involved (figure 1D) $\left(\mathrm{R}^{2}=0.27531, \mathrm{p}<0.001\right)$ or the number of countries, and the number of citations received $\left(R^{2}=0.16181, p=0.003\right)$ (figure $1 \mathrm{E}$ ). Table 3 shows further analysis of top-cited articles in list $\mathrm{A}$ in regard to authorship, institutes involved, countries and grants received. No correlation was found between the number of authors of top-cited articles and the number of citations $\left(\mathrm{R}^{2}=0.0452, \mathrm{p}=0.130\right)$ (figure $1 \mathrm{~F}$ ).

Most articles originated from the USA $(\mathrm{n}=31,57.4 \%)$, Spain $(n=6,11.1 \%)$, the UK $(n=4,7.4 \%)$, France $(n=3$, $5.5 \%)$, Canada $(\mathrm{n}=2,3.7 \%)$, the Netherlands $(\mathrm{n}=2$, $3.7 \%$ ), Belgium, Italy, Japan, Germany, Switzerland and China (Hong Kong) ( $\mathrm{n}=1,1.8 \%$ ) for each country.

Careful assessment of the authorship of top-cited articles shows that some authors contributed to more than one article in the list. Bruix was the first author of three articles, ${ }^{25} 2839$ and was the second and third author of two other articles. ${ }^{52}{ }^{63}$ In his pioneering work, the author focused on the clinical management of hepatocellular carcinoma 25283952 and prognosis of hepatocellular carcinoma. ${ }^{63}$ Llovet co-authored three articles with
Bruix. ${ }^{28} 5263$ Also, Sherman co-authored three articles with Bruix. ${ }^{25} 28{ }^{39}$ Lok was the first author of two articles $^{4466}$ and co-authored one article. ${ }^{58}$ These articles were on chronic hepatitis $\mathrm{B},{ }^{44}{ }^{66}$ and assessment of a simple non-invasive index for predicting fibrosis and cirrhosis in patients with chronic hepatitis C. ${ }^{58}$ Ishak was the first author of one article ${ }^{27}$ and co-authored another article. ${ }^{26}$ These articles were on histological grading and staging of chronic hepatitis, ${ }^{27}$ and the use of a numerical scoring system for assessing histological activity in patients with asymptomatic chronic active hepatitis. ${ }^{26}$ Desmet was the first author of one article ${ }^{31}$ and co-authored another article with Ishak. ${ }^{27}$ Bedossa was the first author of two articles. ${ }^{36} 78$ These articles were on an algorithm for the grading of activity in chronic hepatitis $\mathrm{C}^{36}$ and sample variability of liver fibrosis in chronic hepatitis C. ${ }^{78}$ McCullough was a co-author of two articles. ${ }^{30}{ }^{42}$ Both articles were on non-alcoholic fatty liver disease. Strader was the first author of one article $^{59}$ and a co-author of another article, ${ }^{41}$ both articles were on management of hepatitis C. Winawer was the first author of two articles. ${ }^{47} 50$ These articles were on colorectal cancer. Fletcher co-authored with Winawer on two articles. ${ }^{47}{ }^{50}$ No correlation was found between the number of grants received and the number of citations received $\left(\mathrm{R}^{2}=0.0257, \mathrm{p}=0.247\right)$.

\section{Top-cited articles identified by keyword search (list B)}

Online supplementary appendix 2 summarises the topcited articles on gastroenterology or hepatology identified by searching the Web of Science across all journals (list B). ${ }^{25} 33$ 79-119 Articles are listed in descending order by rank from 1 to 50 based on the absolute number of citations received as of the day of the search.

Table 4 shows that these articles were published over a 35-year period (from 1973 to 2008). During the period 

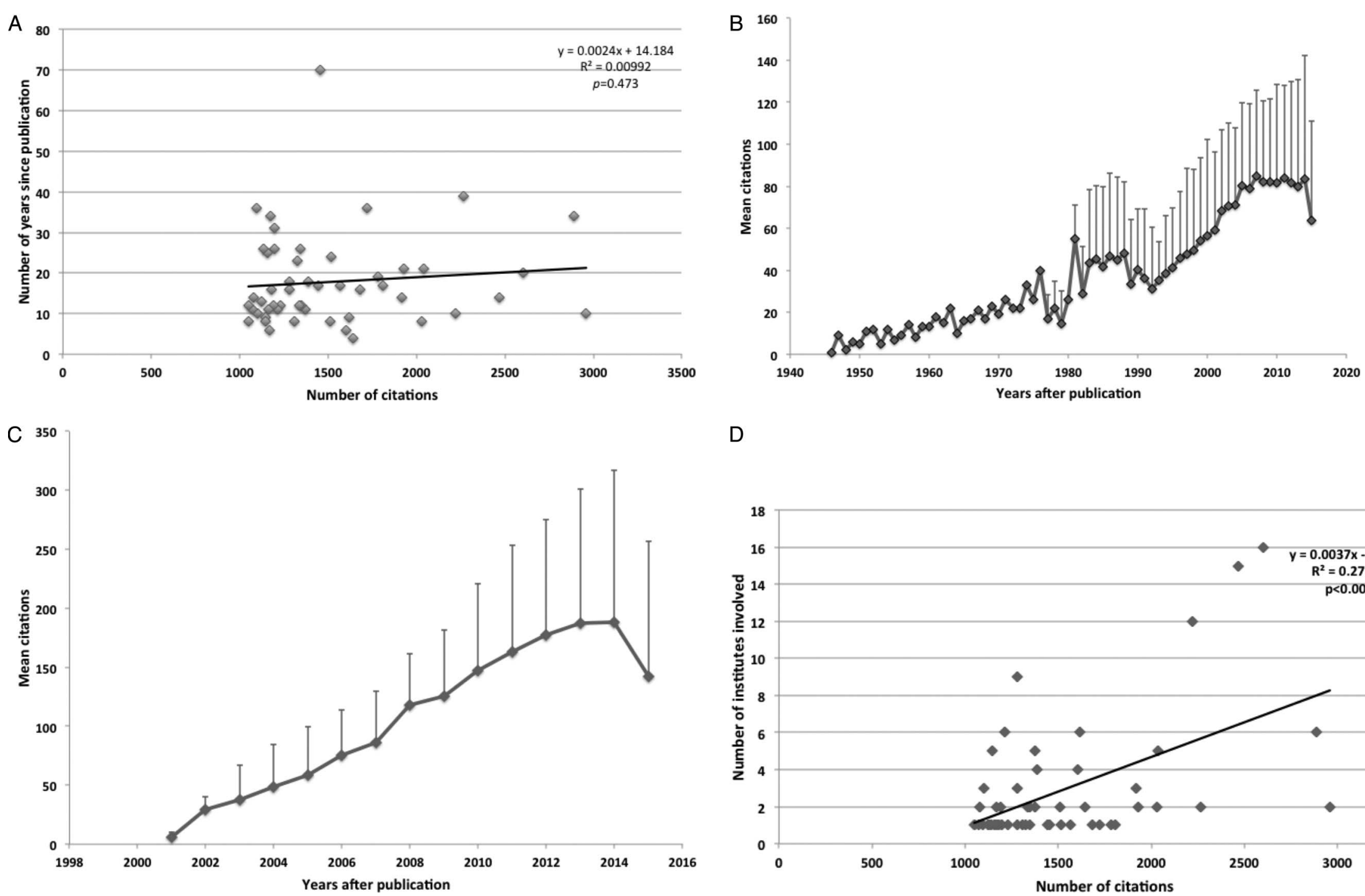

D

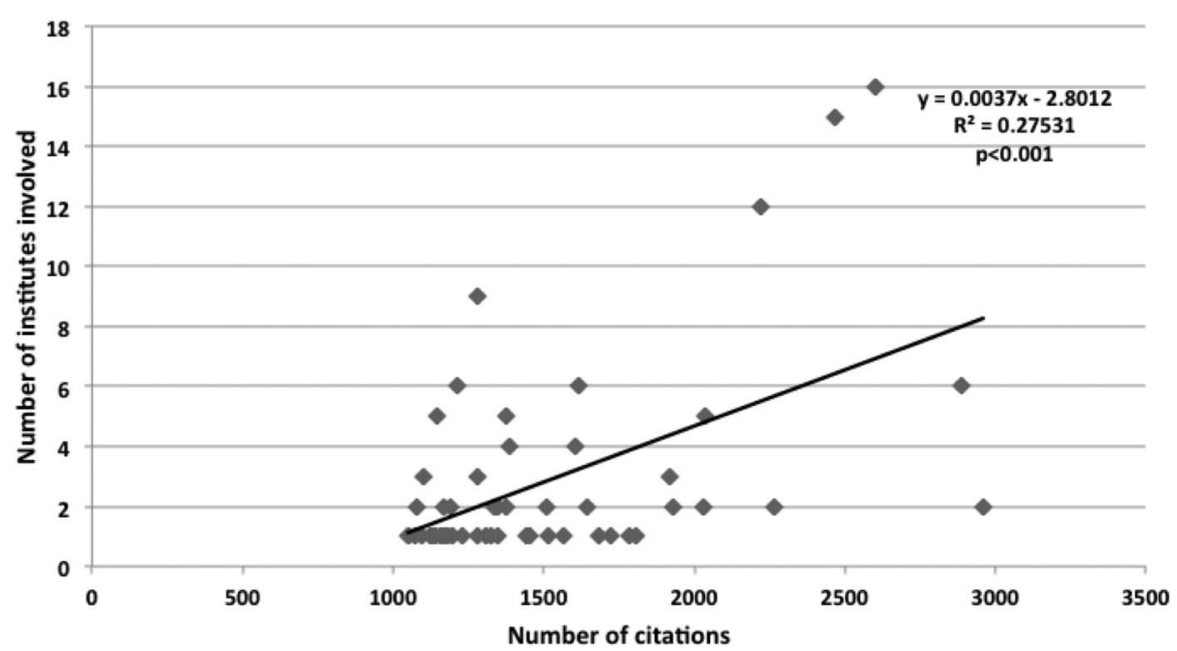

Figure 1 (A) Top-cited gastroenterology and hepatology articles identified by searching journals (list A): correlation between the number of citations and the number of years since publication, (B) Number of citations of papers published before the year 2000 (mean \pm SD), (C) Number of citations of papers published after the year 2000 (mean \pm SD), (D) Top-cited gastroenterology and hepatology articles identified by searching journals (list A): correlation between the number of citations and the number of institutions involved, (E) Top-cited gastroenterology and hepatology articles identified by searching journals (list A): correlation between the number of citations and the number of countries, (F) Top-cited gastroenterology and hepatology articles identified by searching journals (list $A$ ): correlation between the number of citations and the number of authors, and (G) Top-cited gastroenterology and hepatology articles identified by searching journals (list B): correlation between the number of citations and the number of years since publication. 

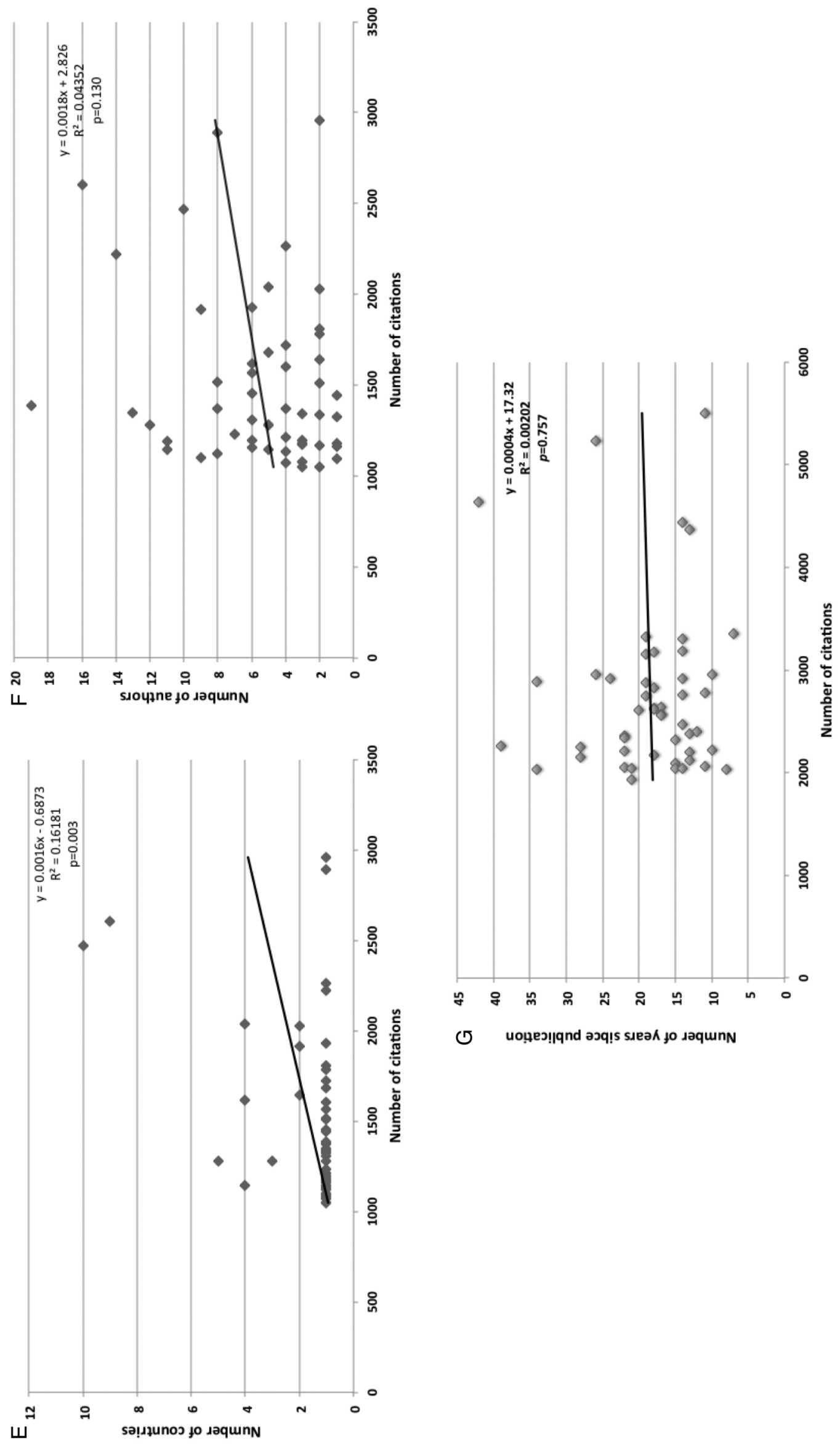

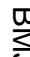

○

$\overrightarrow{\mathrm{B}}$

$\frac{\overline{0}}{\frac{0}{0}}$

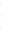

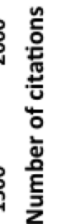

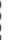

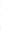

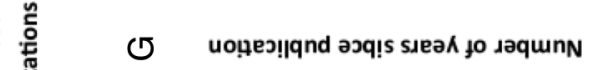

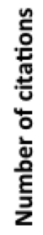

हैं

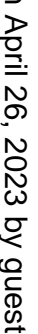



$\underset{0}{0}$

$\frac{\mathbb{\Phi}}{\stackrel{0}{\circ}}$

$\stackrel{1}{2}$

혼

음 
Table 3 Further analysis of the 50 top-cited papers on gastroenterology and hepatology

\begin{tabular}{|c|c|c|c|c|c|}
\hline Variable & Number & Median & IQR & Mean \pm SD & $p$ Value \\
\hline \multicolumn{6}{|c|}{ Number of authors } \\
\hline Males & 254 & 4 & 4 & $4.70 \pm 3.27$ & 0.004 \\
\hline Females & 45 & 1 & 1 & $2.04 \pm 2.01$ & \\
\hline \multicolumn{6}{|c|}{ Institutes involved } \\
\hline 1 & 26 & 1 & 0 & $1.00 \pm 0.00$ & $<0.001$ \\
\hline $2-3$ & 16 & 2 & 0.25 & $2.25 \pm 0.44$ & \\
\hline$>3$ & 12 & 7.75 & 4.75 & $7.75 \pm 4.26$ & \\
\hline \multicolumn{6}{|l|}{ Countries } \\
\hline 1 & 44 & 1 & 0 & $1.00 \pm 0.00$ & $<0.001$ \\
\hline $2-3$ & 4 & 2 & 0.25 & $2.25 \pm 0.50$ & \\
\hline$>3$ & 6 & 4.5 & 4.0 & $6.00 \pm 2.75$ & \\
\hline \multicolumn{6}{|c|}{ Grant support† } \\
\hline Yes & $21 \ddagger$ & 0 & 2 & $0.85 \pm 1.20$ & \\
\hline No & 33 & 0 & 0.0 & 0 & \\
\hline
\end{tabular}

${ }^{*}$ The analysis comprises 54 top-cited articles (list A).

†Some projects received grants from more than one body.

‡Only 10 top-cited articles published after the year 2000 were supported by grants.

from 1973 to 1987, only six articles (12\%) were published. However, the number increased progressively over the years from 1988 to 2008, making a total of 44 $(88 \%)$ articles. Table 5 summarises the distribution of gastroenterology or hepatology topics in relation to the four categories. The majority of top-cited articles were research papers $(\mathrm{n}=38,76 \%)$. The remaining were reviews $(n=8,16 \%)$ and articles $(n=3,6)$. Only one article $(2 \%)$ was an educational guide. The topics can be summarised as follows: colorectal cancer $(n=12$, $24 \%)$, chronic hepatitis and viral hepatitis $(\mathrm{n}=9,18 \%)$, hepatocellular carcinoma $(\mathrm{n}=7,14 \%)$, inflammatory bowel disease $(\mathrm{n}=6,12 \%)$, gastritis, gastric ulcer and $H$. pylori $(\mathrm{n}=4,8 \%)$, and Escherichia coli and diarrhoeal diseases $(n=3,6 \%)$. The distribution of the remaining topics is shown in table 5 .

The top-cited articles were published in 17 journals. Of these, three were specialised in the field ( $n=$ number of articles, \%): Hepatology $(\mathrm{n}=4,8 \%)$, Gastroenterology $(n=3,6 \%)$ and Journal of Hepatology $(n=2,4 \%)$. The majority were published in journals not dedicated to the specialty ( $\mathrm{n}=$ number of articles, \%): New England Journal of Medicine $(\mathrm{n}=16,32 \%)$, Science $(\mathrm{n}=5,10 \%)$, Nature $(\mathrm{n}=5,10 \%)$, Lancet $(\mathrm{n}=3,6 \%)$, Cell $(\mathrm{n}=2,4 \%)$, Journal of Clinical Oncology ( $\mathrm{n}=2,4 \%)$, Nature Genetics $(\mathrm{n}=1,2 \%)$, British Journal of Surgery $(\mathrm{n}=1,2 \%), D N A$ Research $(\mathrm{n}=1,2 \%)$, Clinical Microbiology Reviews ( $\mathrm{n}=1$, $2 \%)$, Cancer Research $(\mathrm{n}=1,2 \%)$, Annals of Internal Medicine ( $\mathrm{n}=1,2 \%)$, American Journal of Surgical Pathology $(\mathrm{n}=1,2 \%)$ and Proceedings of the National Academy of Sciences of the USA $(\mathrm{n}=1,2 \%)$ (see online supplementary appendix 2).

The most frequently cited article was 'Bevacizumab plus irinotecan, fluorouracil, and leucovorin for metastatic colorectal cancer', by Hurwitz et $a l^{79}$ published in New England Journal of Medicine and cited 5500 times over 11 years. The article ranked 50 was 'Up-regulation of cyclooxygenase 2 gene expression in human colorectal adenomas and adenocarcinomas', by Eberhart et $a l^{33}$ published in Gastroenterology and cited 1929 times over 21 years. There was no correlation between the number of citations of these papers and the number of years since publication $\left(\mathrm{R}^{2}=0.00202, \mathrm{p}=0.757\right.$ ) (figure $\left.1 G\right)$. Most articles were from universities in the USA $(n=32$, $64 \%)$, Spain $(n=4,8 \%)$, the UK $(n=3,6)$, France $(n=2$, $4 \%)$, Japan $(\mathrm{n}=2,4 \%)$, Germany, Italy, Finland, Greece, Canada, Belgium and Taiwan $(\mathrm{n}=1,2 \%)$ for each country.

Some authors contributed to more than one article in list B. In addition to the five articles published by Bruix and included in list A, ${ }^{25} 28395263$ were two articles in list B. ${ }^{84} 103$ These articles were on hepatocellular carcinoma. Interestingly, 24 authors had authored or co-authored more than one article in list $\mathrm{A}$ and 29 authors had more than one article in list B. Those who contributed to both lists were: Bond JH, Bruix J, Llovet JM, Mann SM, JP, Miller LL, Rosen L and Winawer SJ (table 6).

Based on the number of citations attracted by topcited articles in list $\mathrm{B}$, we looked at the ranking of these articles in the journals they were published in (the 14 journals that were not specialised in gastroenterology and hepatology). It was interesting to note that five of the top-cited articles were ranked number 1 in their respective journals (ranked number 1 means an article receiving the highest number of citations compared to all articles published in the journal). These articles were published in the following five journals-Journal Impact Factor (JIF) ${ }^{\text {reference }}$ British Journal of Surgery 5.542, ${ }^{81}$ American Journal of Surgical Pathology 5.145, ${ }^{93}$ Journal of Clinical Oncology 18.428, ${ }^{94}$ DNA Research $5.477^{96}$ and Clinical Microbiology Reviews 17.406. ${ }^{101}$ 
Table 5 Top-cited articles by searching keywords for all journals listed in the Science Citation Index Expanded database (list B): by article topic and category ${ }^{\star}$

\begin{tabular}{|c|c|c|c|c|c|}
\hline \multirow[b]{2}{*}{ Topict } & \multicolumn{5}{|c|}{ Category: number of articles (references) } \\
\hline & Article & Review & $\begin{array}{l}\text { Practical } \\
\text { guidelines }\end{array}$ & Research & Total (\%) \\
\hline Gastritis, gastric ulcer, Helicobacter pylori & $1^{93}$ & & & $3^{8892118}$ & $4(8)$ \\
\hline Escherichia coli and diarrhoeal disease & & $1^{101}$ & & $2^{8696}$ & $3(6)$ \\
\hline Chemotherapy and gastrointestinal toxicity & & & & $1^{107}$ & $1(2)$ \\
\hline Stromal tumours & & & & $1^{104}$ & $1(1.9)$ \\
\hline Pancreatic cancer & & & & $1^{94}$ & $1(1.9)$ \\
\hline Inflammatory bowel disease & & $1^{113}$ & & $5^{29879199111}$ & $6(12)$ \\
\hline Colorectal cancer & & $2^{85102}$ & & $10^{33} 7995100105106109114116117$ & $12(24)$ \\
\hline Chronic hepatitis and viral hepatitis & $1^{27}$ & $1^{31}$ & & $7^{268082839098115}$ & $9(18)$ \\
\hline Fatty liver disease & & $1^{110}$ & & $1^{30}$ & $2(4)$ \\
\hline Oesophageal varices & & & & $1^{81}$ & $1(2)$ \\
\hline Bilirubin and hepatic transporters & & & & $2^{108112}$ & $2(4)$ \\
\hline Haemochromatosis & & & & $1^{97}$ & $1(2)$ \\
\hline Hepatocellular carcinoma & $1^{28}$ & $2^{32103}$ & $1^{25}$ & $3^{8489119}$ & $7(14)$ \\
\hline Total (\%) & $3(6)$ & $8(16)$ & $1(0)$ & $38(76)$ & $50(100)$ \\
\hline
\end{tabular}

Eleven top-cited articles were ranked between 2 and 50 in the journals they were published in. The articles were published in the following eight journalsJIF ${ }^{\text {reference: }}$ Journal of Clinical Oncology 18.428, ${ }^{94114}$ Annals of Internal Medicine $17.810,{ }^{115}$ Lancet 45.217, ${ }^{82} 103$ Nature Genetics 29.352, ${ }^{97}$ New England Journal of Medicine 55.873, ${ }^{79} 8384$ Cancer Research $9.329,{ }^{102}$ Cell 32.242 ${ }^{85}$ and Science 33.611. ${ }^{80}$

\section{Comparing lists A and B}

The total number of citations for all the 54 articles included in list A was 81324.0 and 138012.0 for the 50 articles in list B. The median number (IQR) of citations for top-cited articles in list A was $1340.0 \quad(\mathrm{IQR}=529.5)$ and 2585.5 (IQR=739.2) for list B.

Several universities or research centres contributed to more than one article. For example, Mayo Clinic and Mayo Foundation, Rochester, Minnesota; $;^{34} 5767110$ and the University of Michigan Medical Center, Michigan, ${ }^{44586691}$ each contributed four articles. Other research centres contributed two articles each. These were: The National Center Institute, Bethesda, Maryland; ${ }^{30} 108$ University Hospital of Cleveland, Cleveland; ${ }^{42} 46$ The Upjohn Company, Kalamazoo, Michigan; ${ }^{37} 74$ Duke University Center, Durham, North Carolina; ${ }^{43} \quad 79$ Johns Hopkins Oncology Center, Baltimore, Maryland; ${ }^{85} 100$ and University of Wisconsin, Madison, Wisconsin. ${ }^{69} 86$ In Spain, the top-cited articles originated from the University of Barcelona 253952 and Barcelona-Clinic Liver Cancer Group, Institut d'Investigacions Biomèdiques August Pi i Sunyer, Liver Unit, Hospital Clínic, Barcelona, Catalonia. ${ }^{28} 5263$

Figure 2 shows the citations $($ mean $\pm \mathrm{SD})$ attracted by top-cited articles in lists A and B for each type of paper (Practical Guide, Research, Article and Review). Further analysis showed no significant differences between the number of citations attracted by each type in the two lists $(\mathrm{p}=0.803)$.

Table 7 summarises the type of research in both lists. In list $\mathrm{B}$, randomised controlled trials $(\mathrm{n}=15,30 \%)$ and cohort studies $(n=8,16 \%)$ were dominant, while in list A, cross-sectional studies $(n=3,5.9 \%)$, a case-control study $(n=1,2 \%)$, experimental studies $(n=9,17.6 \%)$ and causal-comparative studies $(n=5,9.8 \%)$ were observed. Four research studies were identified in both lists. $^{26} 293033$ The inter-rater agreement between evaluators had a Cohen $\kappa$ coefficient of $0.76-0.84$.

\section{DISCUSSION}

The aim of this study was to identify the 50 top-cited articles in gastroenterology and hepatology, and to gain insight into the characteristics of the top-cited articles in the field. Citation analysis may offer the opportunity to gain insight into peer recognition of articles that added to the discipline. To ensure that our search had included articles published in journals other than those dedicated to the discipline, a second search was conducted using keywords (list B). The latter search covered all journals listed in the SCI-Expanded regardless of specialty. The number of citations attracted by articles included in list B was significantly higher than those in list A. This may be proportional to the JIF of the journals in which the articles were published. Interestingly, the articles in list A were published in 10 journals with the highest JIF in the category 'Gastroenterology and Hepatology' listed in the 2014 JCR. The finding that the majority of articles in list B were from journals not in the field, reflects the integrative nature of the specialty with the role of basic sciences and clinical studies in the 


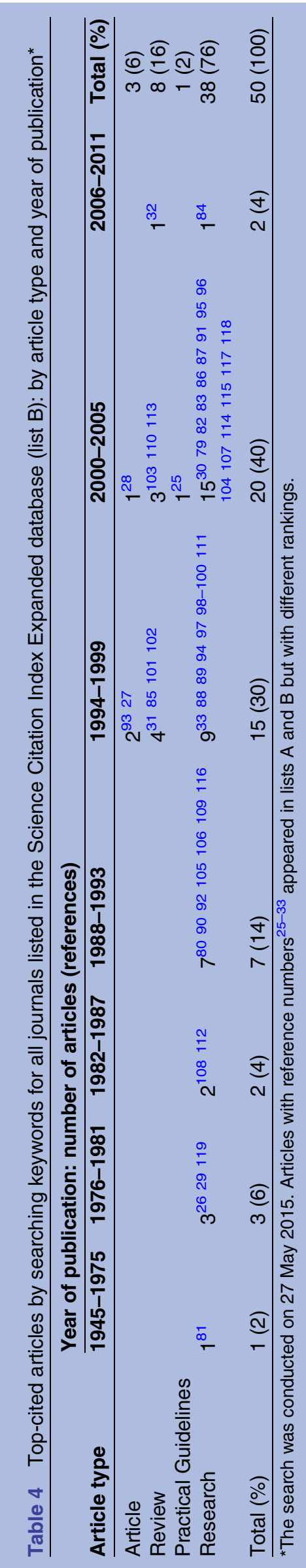

development of Gastroenterology and Hepatology. It also shows the interest of editors and readers in journals such as New England Journal of Medicine, Annals of Internal Medicine and Lancet in gastroenterology and hepatology topics.

The study provided an insight into the trends in publications over the past 60-70 years. Top-cited articles from the 1950 s to the late 1970 s dealt primarily with animal models for the study of gastric ulcerations, ${ }^{45}$ cytoprotection of gastric mucosa by prostaglandins, ${ }^{37} 74$ animal models for intestinal ischaemia, ${ }^{65}$ the development of a numerical scoring system for assessing histological activity in patients with chronic active hepatitis ${ }^{26}$ and the development of Crohn's disease activity index. ${ }^{29}$ During the 1980s to early 1990s, the articles focused on animal models of inflammation and ulcerations in the colon, ${ }^{60} 6168$ localisation of the multidrug-resistant gene product, p-glycoprotein, ${ }^{108}$ and the biology of bilirubin, ${ }^{112}$ non-A and non-B viral hepatitis, ${ }^{80} 90$ and colorectal cancer. 4951105106109116

From 1994 to 2005, top-cited articles focused on three hepatology topics: (1) steatohepatitis and fatty

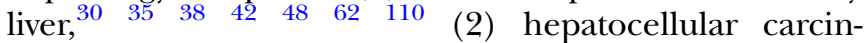
oma, ${ }^{25} \quad 28 \quad 52 \quad 63 \quad 72 \quad 76 \quad 89 \quad 103$ and (3) viral hepatitis C diagnosis and treatment, ${ }^{36} 58597378828398115$ as well as three gastroenterology topics: (1) colorectal cancer, ${ }^{47} 50 \quad 75798595102104114117$ (2) inflammatory bowel disease and colitis, ${ }^{46} 678799113$ and E. coli and diarrhoeal diseases. ${ }^{86} 96101$ The studies after 2006 continued to explore new aspects related to hepatocellular cancer, ${ }^{32} 3954$ hepatitis $\mathrm{B}^{4466}$ and hepatitis $\mathrm{C}^{41}$

With regard to clinical relevance, the articles reflect the hidden burden of chronic hepatitis B and C infections, which the former US Assistant Secretary for Health, Dr Howard Koh, described as the 'Silent Epidemic', ${ }^{120}$ and highlight the need for strategies to prevent and manage liver cancer ${ }^{121}$ and colorectal cancer. In USA, over 1.3 million people suffer from inflammatory bowel disease and, despite extensive research in this area, we are still unable to identify the exact cause of the disease or to have clear preventive strategies or an effective cure. ${ }^{122}$ In the USA, colorectal cancer is the second leading cause of cancer-related deaths in males and in females. It is the third most common cancer in men and in women. ${ }^{123}$ Therefore, the scientific and research relevance of the top-cited articles identified in the two lists reflects the emerging needs of these areas and the new developments in our understanding of these disorders.

Although it may take 15 years or more for articles to reach a peak in the overall citation number, ${ }^{124}$ it was noted that a number of top-cited articles in both lists were only 8 or less years old. 323941445466707784 Only four articles were published after 2007. However, the article by Shay et $a l,{ }^{45}$ on animal model for the study of gastric ulcers, was 70 years old (published in 1945). Careful scrutiny showed that the article is still attractive to researchers and was cited 10 times in 2015, 23 times 
Table 6 Authors and co-authors of two or more articles of top-cited articles in gastroenterology and hepatology identified by searching gastroenterology and hepatology journals (list A) or by searching keywords for all journals listed in the Web of Science (list B)*

\begin{tabular}{|c|c|c|c|c|c|}
\hline \multicolumn{3}{|l|}{ List A } & \multicolumn{3}{|l|}{ List $B$} \\
\hline \multirow[b]{2}{*}{ Author's name† } & \multicolumn{2}{|c|}{ Number references } & \multirow[b]{2}{*}{ Author's name } & \multicolumn{2}{|c|}{ Number references } \\
\hline & First author & Co-author & & First author & Co-author \\
\hline Bedossa P & $2^{3678}$ & - & Albrecht JK & - & $2^{8298}$ \\
\hline Bond JH & - & $2^{4750}$ & Blanke CD & - & $2^{104117}$ \\
\hline Bruix J‡ & $3^{2528} 39$ & $2^{5263}$ & Bond JH & - & $1^{105116}$ \\
\hline Desmet V & $1^{31}$ & $1^{27}$ & Bruix J & - & $2^{84103}$ \\
\hline Fletcher R & - & $2^{4750}$ & Choo QL & $1^{80}$ & $1^{90}$ \\
\hline Ishak K & $1^{27}$ & $1^{26}$ & Diago M & - & $2^{83115}$ \\
\hline Lok AS & $2^{4466}$ & $1^{58}$ & Fehrenbach L & - & $2^{79} 117$ \\
\hline Llovet JM‡ & $2^{5263}$ & $1^{28}$ & Goodman ZD & - & $2^{8298}$ \\
\hline Lynch HT & - & $2^{4955}$ & Gordon SC & - & $2^{8298}$ \\
\hline Manns Mł & - & $1^{31}$ & Hamilton SR & - & $2^{210106}$ \\
\hline McCullough JA & - & $2^{3042}$ & Hüssinger D & - & $2^{8384}$ \\
\hline McMahon BJ & - & $2^{4466}$ & Kinzler KW & $1^{85}$ & $1^{100}$ \\
\hline Mecklin JP $\ddagger$ & - & $1^{4955}$ & Kuo G & $1^{90}$ & $1^{80}$ \\
\hline Miller LL‡ & - & $1^{47}$ & $\operatorname{Lin} A$ & - & $2^{83115}$ \\
\hline Rosen L‡ & - & $1^{47}$ & Ling $M$ & - & $2^{8298}$ \\
\hline Sherman M & - & $3^{252839}$ & Llovet JM & $2^{84103}$ & - \\
\hline Strader DB & $1^{59}$ & $1^{41}$ & Manns M & $1^{82}$ & - \\
\hline Talley NJ & - & $1^{5657}$ & Mazzaferro V & $1^{89}$ & $1^{84}$ \\
\hline Thomas DL & - & $2^{4159}$ & McHutchison JG & $1^{98}$ & $1^{82}$ \\
\hline Thompson WG & - & $1^{4056}$ & Mecklin JP & - & $1^{106}$ \\
\hline Vakil N & $1^{69}$ & $1^{70}$ & Miller LL & - & $1^{86117}$ \\
\hline Vasen HF & $2^{4955}$ & - & Moore MJ & - & $2^{94117}$ \\
\hline Winawer SJ‡ & $2^{4750}$ & - & Rosen L & - & $1^{117}$ \\
\hline \multirow[t]{6}{*}{ Woolf S } & - & $2^{4750}$ & Rustgi VK & - & $2^{8298}$ \\
\hline & & & Santoro A & - & $2^{8495}$ \\
\hline & & & Shiffman M & - & $3^{828398}$ \\
\hline & & & Williams R & - & $2^{7181}$ \\
\hline & & & Winawer SJ & $1^{105}$ & \\
\hline & & & Zeuzem S & - & $2^{84115}$ \\
\hline
\end{tabular}

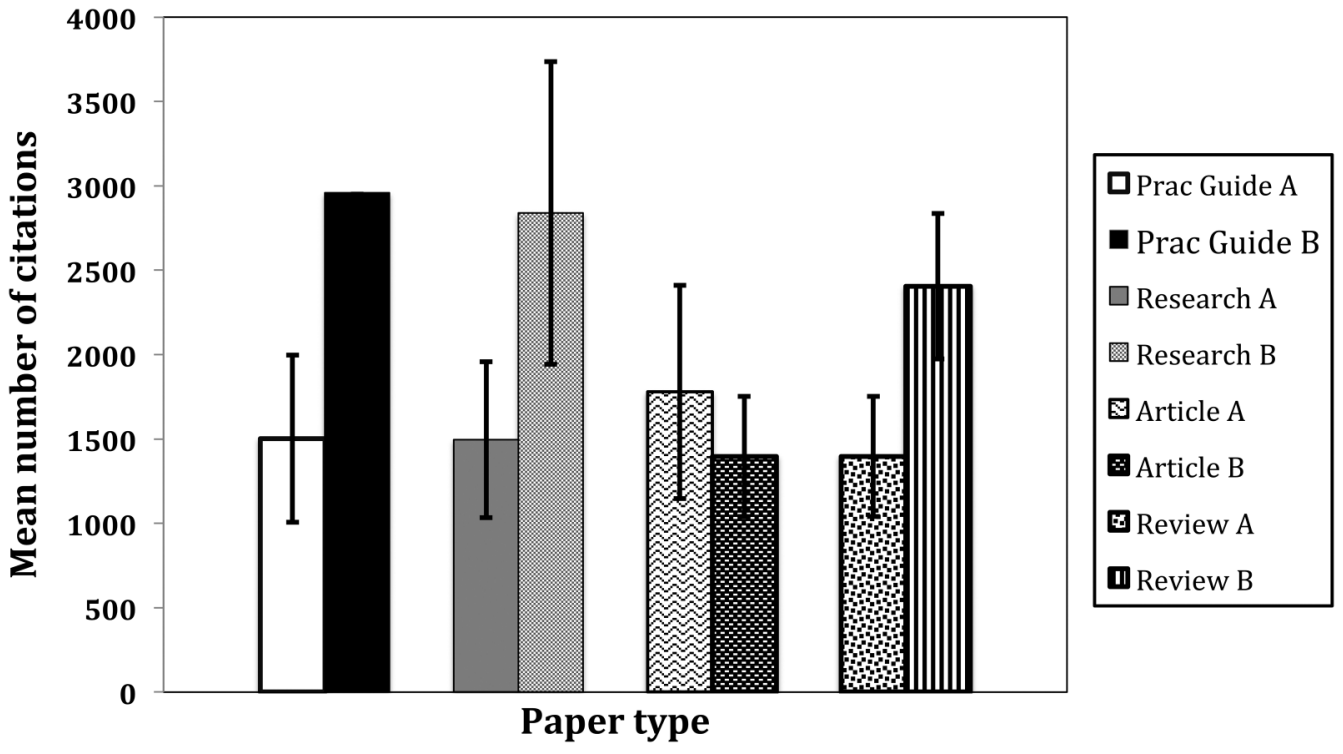

Figure 2 Citations ( $m e a n \pm S D$ ) attracted by top-cited papers in lists $A$ and $B$ for each paper type. 
Table 7 Top-cited research articles in gastroenterology and hepatology identified by searching gastroenterology and hepatology journals (list A) or by searching keywords for all journals listed in the Web of Science (list B): by article topic and research type*

\begin{tabular}{|c|c|c|c|c|c|c|}
\hline \multirow[b]{2}{*}{ Topic } & \multicolumn{6}{|c|}{ Research type: number of articles (references) } \\
\hline & $\begin{array}{l}\text { Cross- } \\
\text { sectional } \\
\text { study }\end{array}$ & $\begin{array}{l}\text { Case- } \\
\text { control } \\
\text { study }\end{array}$ & $\begin{array}{l}\text { Cohort } \\
\text { study }\end{array}$ & $\begin{array}{l}\text { Randomised } \\
\text { controlled trial }\end{array}$ & $\begin{array}{l}\text { Experimental } \\
\text { study }\end{array}$ & $\begin{array}{l}\text { Causal- } \\
\text { comparative } \\
\text { study }\end{array}$ \\
\hline $\begin{array}{l}\text { Gastro-oesophageal reflux } \\
\text { disease }\end{array}$ & $1^{57}$ & & & & & \\
\hline $\begin{array}{l}\text { Gastritis, gastric ulcer, } \\
\text { Helicobacter pylori }\end{array}$ & & & $2^{92118}$ & & $2^{4588}$ & \\
\hline $\begin{array}{l}\text { Prostaglandins and gastric } \\
\text { protection }\end{array}$ & & & & & & $1^{37}$ \\
\hline $\begin{array}{l}\text { Functional gastrointestinal } \\
\text { disorders }\end{array}$ & $1^{56}$ & & & & & \\
\hline $\begin{array}{l}\text { Escherichia coli and } \\
\text { diarrhoeal disease }\end{array}$ & & & & & $2^{8696}$ & \\
\hline $\begin{array}{l}\text { Chemotherapy and } \\
\text { gastrointestinal toxicity }\end{array}$ & & & & $1^{107}$ & & \\
\hline Pancreatic cancer & & & & $1^{94}$ & & \\
\hline Intestinal ischaemia & & & & & & $1^{65}$ \\
\hline Inflammatory bowel disease & & & & $1^{111}$ & $6^{6068879199113}$ & $2^{2961}$ \\
\hline Colorectal cancer & & $1^{33}$ & $2^{105106}$ & $6^{79} 95104114116117$ & $3^{51100109}$ & \\
\hline Stromal tumours & & & & & & \\
\hline $\begin{array}{l}\text { Chronic hepatitis and viral } \\
\text { hepatitis }\end{array}$ & & & $4^{58737890}$ & $4^{82} 8398115$ & $3^{263680}$ & \\
\hline Fatty liver disease & $2^{4862}$ & & $1^{42}$ & & $1^{30}$ & \\
\hline Oesophageal varices & & & $1^{81}$ & & & \\
\hline $\begin{array}{l}\text { Bilirubin and hepatic } \\
\text { transporters }\end{array}$ & & & & & $1^{108}$ & \\
\hline Haemochromatosis & & & & & $1^{97}$ & \\
\hline $\begin{array}{l}\text { End-stage liver disease and } \\
\text { liver failure }\end{array}$ & & & & & $1^{34}$ & $1^{71}$ \\
\hline Hepatocellular carcinoma & & & $2^{89119}$ & $2^{7284}$ & $1^{54}$ & \\
\hline Total & 4 & 1 & 12 & 15 & 21 & 5 \\
\hline
\end{tabular}

in 2014 and 25 times in 2013. Top-cited articles are frequently cited but this tendency does not necessarily indicate that these papers are great. For example, the most cited work in history is the paper by Lowry et al, a 1951 paper describing an assay to determine the amount of protein in a solution. It has gathered, at the time of submitting this manuscript, 311819 citations, although several new techniques for measuring protein in a solution and several modified techniques to this method have been developed and described in the literature over the past 65 years. ${ }^{125}$ However, such papers are exceptions and do not represent a general trend.

As shown from this study, there was no correlation between the number of citations and the number of years since the paper was published. This was demonstrated for articles included in both lists. The finding may be related to the tendency of researchers to cite particular papers. This may become standard practice to make clearer to other scientists the type of methods these individuals followed in their research. ${ }^{18}$ It has been shown from this study that the mean numbers of citations of articles published after the year 2000 are higher than those published before 2000 , not necessarily because of their quality but due to the tendency of researchers to preferentially cite the most recent studies.

This study also showed no correlation between number of authors or number of grants received and number of citations, but demonstrated strong correlations between the number of institutes involved or number of countries and the number of citations. Females were under-represented in authorship (45 vs $254, p=0.004)$. In neither list were significant differences found between the number of citations attracted by each type of paper-Practical Guide, Research, Article and Review-which may highlight the equal significance and usefulness of each type to researchers and clinicians.

These findings are consistent with those of Danthi et $a l^{126}$ who, in a large cohort of the National Heart, Lung, and Blood Institute (NHLBI) grant-funded research, reported that they were unable to find a monotonic association between better percentile ranking and higher scientific impact as assessed by citation 
metrics. ${ }^{126}$ Again, Fortin and Currie, ${ }^{127}$ in a study evaluating how scientific impact scales with funding, concluded that their findings are inconsistent with the hypothesis that larger grants lead to larger discoveries. The issue of female authorship in major academic gastroenterology journals has been recently studied. The authors found that the percentage of US female physician authors of original research in major gastroenterology journals is lower than expected, although it has increased over time. ${ }^{128}$

While writing this study, we came across a recently published article by Tang et al, ${ }^{129}$ who used three key search words to identify top-cited article on the digestive system. The method used was briefly described and there was no list of top-cited articles to compare with our list. However, it was noticed that, out of a list of 100 articles, Tang et al identified only eight articles from Gastroenterology, while this study identified 26 articles among top-cited articles in list A. They identified five institutions with two or more articles, while in this study, more than 10 centres were identified. They reported only two top-cited articles each from Mayo Clinic and Mayo Foundation, Rochester, Minnesota, and from the University of Michigan Medical Center, Michigan, while this study identified four articles from each of these institutions. Several centres that contributed to more than one article were not mentioned in Tang's study. Also, they only identified six authors who had authored or co-authored two or more top-cited articles, while, as per the results from this study, 24 authors in list A and 29 authors in list B had authored or co-authored more than one top-cited article (table 6). These differences may be related to differences in the methodology used and possibly the depth in analysing data collected.

However, this study is not without limitations. First, the search used was based on journals with high impact factor. This may have contributed to the increased number of articles from Western countries, especially the USA, the UK and Canada. Therefore, articles in languages other than English, which may have impact in the field, were not included. However, our findings show that Spain was the second country that contributed to most-cited articles in lists A and B. Recently, Iñigo and García-Samaniego, in an elegant article, conducted a bibliometric analysis of publications in gastroenterology and hepatology in Spain, from 2000 to 2009. The paper was written in the Spanish language. ${ }^{20}$ Second, authors' self-citations were not excluded from the total number of citations, and absolute number of citations was used. Third, the search was conducted using the Science Citation Index Expanded database, and there is the possibility that the database filter is not sensitive enough to the search words. However, in this study, 69 journals specialised in the field were searched and more than 40 keywords were used in the search with the aim to maximise the yield. Fourth, the 50 top-cited articles in the two lists represent an arbitrary number and the findings represent the outcomes at the time of conducting the search. One of the strengths of this study is the search for the top 50 frequently cited papers, using two search methods.

\section{CONCLUSIONS}

The citation analysis in this study compiled two lists of the top 50 highly cited articles in gastroenterology and hepatology. The first list (list A) was constructed by searching 69 journals in the field. List B was constructed by searching the Science Citation Index Expanded database, using keywords. The citations varied from 1049 and 2959 in list A and from 1929 to 5500 in list B. The articles were published between 1945 and 2011, with the number of articles increasing progressively from 1988 to 2011. In both lists, research papers dominated top-cited articles. Randomised controlled trials and cohort studies dominated research in list $\mathrm{B}$, while in lit A, crosssectional studies, a case-control study and experimental studies were observed. The number of authors or co-authors with more than one article was 24 in list A and 29 in list B. Articles in list B were mainly published in New England Journal of Medicine, Science and Nature. The articles came from over 12 different countries, with the USA most frequently represented followed by Spain. While no correlations were found between the number of authors or the number of grants received, and the number of citations, strong correlations were found between the number of institutes or the number of countries involved, and the number of citations. In neither list was there significant correlation between the number of citations and the number of years since publishing. However, the mean number of citations tended to be higher in papers published after the year 2000, possibly indicating the significance of scientific content and the tendency of researchers to cite recently published work.

Acknowledgements The authors would like to thank Diana Azer for her assistance and review of the manuscript. They also thank Dr Lily Scott for her assistance in this work and Ms Mae Eustaquio for secreterial assistance.

Contributors SAA started the design of the study and contributed to its methodology. SAA and SA searched the databases, collected the data, analysed the findings and created the two lists. SAA and SA also interpreted the findings, ranked the articles, created the tables and figures and drafted the manuscript, as well as contributed to the revision of the manuscript and approved the final manuscript for submission.

Funding This work was supported by the College of Medicine Research Center, Deanship of Scientific Research, King Saud University, Riyadh, Saudi Arabia.

Competing interests None declared.

Provenance and peer review Not commissioned; externally peer reviewed.

Data sharing statement No additional data are available.

Open Access This is an Open Access article distributed in accordance with the Creative Commons Attribution Non Commercial (CC BY-NC 4.0) license, which permits others to distribute, remix, adapt, build upon this work noncommercially, and license their derivative works on different terms, provided the original work is properly cited and the use is non-commercial. See: http:// creativecommons.org/licenses/by-nc/4.0/ 


\section{REFERENCES}

1. Ioannidis JP, Boyack KW, Small $\mathrm{H}$, et al. Bibliometrics: is your most cited work your best? Nature 2014;514:561-2

2. Patsopoulos NA, loannidis JP, Analatos AA. Origin and funding of the most frequently cited papers in medicine: database analysis. BMJ 2006;332:1061-4.

3. Garfield E. Fortnightly review: how can impact factors be improved? BMJ 1996;313:411-13.

4. Garfield E. Is citation analysis a legitimate evaluation tool? Scientometrics 1979;1:359-75.

5. Nicholson JM, loannidis JP. Research grants: conform and be funded. Nature 2012;492:34-6.

6. McVeigh ME, Mann SJ. The journal impact factor denominator: defining citable (counted) items. JAMA 2009;302:1107-9.

7. van Leeuwen $T$. Discussing some basic critique on Journal Impact Factors: revision of earlier comments. Scientometrics 2012;92:443-55

8. King DA. The scientific impact of nations. Nature 2004;430:311-16

9. Callaham M, Wears RL, Weber E. Journal prestige, publication bias, and other characteristics associated with citation of published studies in peer-reviewed journals. JAMA 2002;287:2847-50.

10. Garfield E, Welljams-Dorof A. Of Nobel class: a citation perspective on high impact research authors. Theor Med 1992;13:117-35.

11. Shuaib W, Khan MS, Shahid H, et al. Bibliometric analysis of the top 100 cited cardiovascular articles. Am J Cardiol

2015;115:972-81.

12. O'Sullivan KE, Kelly JC, Hurley JP. The 100 most cited publications in cardiac surgery: a bibliometric analysis. Ir J Med Sci 2015;184:91-9.

13. Cassar Gheiti AJ, Downey RE, Byrne DP, et al. The 25 most cited articles in arthroscopic orthopaedic surgery. Arthroscopy 2012;28:548-64.

14. Tam WW, Wong EL, Wong FC, et al. Citation classics: top 50 cited articles in 'respiratory system'. Respirology 2013;18:71-81.

15. Stern RS, Arndt KA. Top cited authors in dermatology: a citation study from 24 journals: 1982-1996. Arch Dermatol 1999;135:299-302.

16. Azer SA. The top-cited articles in medical education: a bibliometric analysis. Acad Med 2015;90:1147-61.

17. Hung WT, Lee TC, Ying CC. Top 100 cited article in gastroenterology and hepatology: bird-view of research theme and trend over time by bibliometric study. J Gastroenterol Hepatol 2009;24:A35.

18. Van Noorden R, Maher B, Nuzzo R. The top 100 papers. Nature 2014;514:550-3

19. Kulkarni AV, Aziz B, Shams I, et al. Comparisons of citations in Web of Science, Scopus, and Google Scholar for articles published in general medical journals. JAMA 2009;302:1092-6.

20. Iñigo J, García-Samaniego J. Bibliometric analysis of publications in Gastroenterology and Hepatology in Spain from 2000 to 2009. Gastroenterol Hepatol 2012;35:551-9.

21. Lefaivre KA, Guy P, O'Brien PJ, et al. Leading 20 at 20: top cited articles and authors in the Journal of Orthopaedic Trauma, 19872007. J Orthop Trauma 2010;24:53-8.

22. Chiu WT, Ho YS. Bibliometric analysis of homeopathy research during the period of 1991 to 2003. Scientometrics 2005;63:3-23.

23. Li Z, Ho YS. Use of citation per publication as an indicator to evaluate contingent valuation research. Scientometric 2008;75:97-110

24. Nawa RK, Lettvin C, Winkelman C, et al. Initial interrater reliability for a novel measure of patient mobility in a cardiovascular intensive care unit. J Crit Care 2014;29:475.e1-5.

25. Bruix J, Sherman M, Practice Guidelines Committee, American Association for the Study of Liver Diseases. Management of hepatocellular carcinoma. Hepatology 2005;42:1208-36.

26. Knodell RG, Ishak KG, Black WC, et al. Formulation and application of a numerical scoring system for assessing histological activity in asymptomatic chronic active hepatitis. Hepatology 1981;1:431-5.

27. Ishak K, Baptista A, Bianchi L, et al. Histological grading and staging of chronic hepatitis. J Hepatol 1995;22:696-9.

28. Bruix J, Sherman M, Llovet JM, et al. EASL Panel of Experts on HCC. Clinical management of hepatocellular carcinoma. Conclusions of the Barcelona-2000 EASL conference. European Association for the Study of the Liver. J Hepatol 2001;35:421-30.

29. Best WR, Becktel JM, Singleton JW, et al. Development of a Crohn's disease activity index. National Cooperative Crohn's Disease Study. Gastroenterology 1976;70:439-44

30. Kleiner DE, Brunt EM, Van Natta M, et al. Nonalcoholic Steatohepatitis Clinical Research Network. Design and validation of a histological scoring system for nonalcoholic fatty liver disease. Hepatology 2005;41:1313-21.
31. Desmet VJ, Gerber M, Hoofnagle JH, et al. Classification of chronic hepatitis: diagnosis, grading and staging. Hepatology 1994;19:1513-20.

32. El-Serag HB, Rudolph KL. Hepatocellular carcinoma: epidemiology and molecular carcinogenesis. Gastroenterology 2007;132:2557-76.

33. Eberhart CE, Coffey RJ, Radhika A et al. Up-regulation of cyclooxygenase 2 gene expression in human colorectal adenomas and adenocarcinomas. Gastroenterology 1994;107:1183-8.

34. Kamath PS, Wiesner $\mathrm{RH}$, Malinchoc $\mathrm{M}$, et al. A model to predict survival in patients with end-stage liver disease. Hepatology 2001;33:464-70.

35. Day CP, James OF. Steatohepatitis: a tale of two "hits"? Gastroenterology 1998;114:842-5.

36. Bedossa P, Poynard T. An algorithm for the grading of activity in chronic hepatitis C. The METAVIR Cooperative Study Group. Hepatology 1996;24:289-93.

37. Robert A, Nezamis JE, Lancaster C, et al. Cytoprotection by prostaglandins in rats. Prevention of gastric necrosis produced by alcohol, $\mathrm{HCl}, \mathrm{NaOH}$, hypertonic $\mathrm{NaCl}$, and thermal injury. Gastroenterology 1979;77:433-43.

38. Brunt EM, Janney CG, Di Bisceglie AM, et al. Nonalcoholic steatohepatitis: a proposal for grading and staging the histological lesions. Am J Gastroenterol 1999;94:2467-74.

39. Bruix J, Sherman M, American Association for the Study of Liver Diseases. Management of hepatocellular carcinoma: an update. Hepatology 2011;53:1020-2.

40. Longstreth GF, Thompson WG, Chey WD, et al. Functional bowel disorders. Gastroenterology 2006;130:1480-91.

41. Ghany MG, Strader DB, Thomas DL, et al. American Association for the Study of Liver Diseases. Diagnosis, management, and treatment of hepatitis C: an update. Hepatology 2009;49: 1335-74

42. Matteoni CA, Younossi ZM, Gramlich T, et al. Nonalcoholic fatty liver disease: a spectrum of clinical and pathological severity. Gastroenterology 1999;116:1413-19.

43. Cotton PB, Lehman G, Vennes J, et al. Endoscopic sphincterotomy complications and their management: an attempt at consensus. Gastrointest Endosc 1991;37:383-93.

44. Lok AS, McMahon BJ. Chronic hepatitis B. Hepatology 2007;45:507-39.

45. Shay $\mathrm{H}$, Komarov SA, Fels SS, et al. A simple method for the uniform production of gastric ulceration in the rat. Gastroenterology 1945;5:43-61.

46. Flocchi C. Inflammatory bowel disease: etiology and pathogenesis. Gastroenterology 1998;115:182-205.

47. Winawer SJ, Fletcher RH, Miller L, et al. Colorectal cancer screening: clinical guidelines and rationale. Gastroenterology 1997;112:594-642.

48. Browning JD, Szczepaniak LS, Dobbins R, et al. Prevalence of hepatic steatosis in an urban population in the United States: impact of ethnicity. Hepatology 2004;40:1387-95.

49. Vasen HF, Mecklin JP, Khan PM, et al. The International Collaborative Group on Hereditary Non-Polyposis Colorecta Cancer (ICG-HNPCC). Dis Colon Rectum 1991;34: 424-5.

50. Winawer S, Fletcher R, Rex D, et al. Gastrointestinal Consortium Panel. Colorectal cancer screening and surveillance: clinical guidelines and rationale-update based on new evidence. Gastroenterology 2003;124:544-60.

51. Hidalgo IJ, Raub TJ, Borchardt RT. Characterization of the human colon carcinoma cell line (Caco-2) as a model system for intestinal epithelial permeability. Gastroenterology 1989;96:736-49.

52. Llovet JM, Bruix J. Systematic review of randomized trials for unresectable hepatocellular carcinoma: Chemoembolization improves survival. Hepatology 2003;37:429-42.

53. Marsh MN. Gluten, major histocompatibility complex, and the small intestine. A molecular and immunobiologic approach to the spectrum of gluten sensitivity ('celiac sprue'). Gastroenterology 1992;102:330-54.

54. Meng F, Henson R, Wehbe-Janek $\mathrm{H}$, et al. MicroRNA-21 regulates expression of the PTEN tumor suppressor gene in human hepatocellular cancer. Gastroenterology 2007;133: $647-58$.

55. Vasen HF, Watson P, Mecklin JP, et al. New clinical criteria for hereditary nonpolyposis colorectal cancer (HNPCC, Lynch syndrome) proposed by the International Collaborative group on HNPCC. Gastroenterology 1999;116:1453-6.

56. Drossman DA, Li Z, Andruzzi E, et al. US householder survey of functional gastrointestinal disorders. Prevalence, sociodemography, and health impact. Dig Dis Sci 1993;38:1569-80. 
57. Locke GR III, Talley NJ, Fett SL, et al. Prevalence and clinica spectrum of gastroesophageal reflux: a population-based study in Olmsted County, Minnesota. Gastroenterology 1997;112:1448-56.

58. Wai CT, Greenson JK, Fontana RJ, et al. A simple noninvasive index can predict both significant fibrosis and cirrhosis in patients with chronic hepatitis C. Hepatology 2003;38:518-26.

59. Strader DB, Wright T, Thomas DL, et al. American Association for the Study of Liver Diseases. Diagnosis, management, and treatment of hepatitis C. Hepatology 2004;39:1147-71.

60. Morris GP, Beck PL, Herridge MS, et al. Hapten-induced model of chronic inflammation and ulceration in the rat colon. Gastroenterology 1989;96:795-803.

61. Krawisz JE, Sharon P, Stenson WF. Quantitative assay for acute intestinal inflammation based on myeloperoxidase activity. Assessment of inflammation in rat and hamster models. Gastroenterology 1984;87:1344-50.

62. Marchesini G, Bugianesi E, Forlani G, et al. Nonalcoholic fatty liver, steatohepatitis, and the metabolic syndrome. Hepatology 2003;37:917-23

63. Llovet JM, Brú C, Bruix J. Prognosis of hepatocellular carcinoma: the BCLC staging classification. Semin Liver Dis 1999;19:329-38.

64. Lavanchy D. Hepatitis B virus epidemiology, disease burden, treatment, and current and emerging prevention and control measures. J Viral Hepat 2004;11:97-107.

65. Granger DN, Rutili G, McCord JM. Superoxide radicals in feline intestinal ischemia. Gastroenterology 1981;81:22-9.

66. Lok AS, McMahon BJ. Chronic hepatitis B: update 2009. Hepatology 2009;50:661-2.

67. Loftus EV Jr. Clinical epidemiology of inflammatory bowel disease: incidence, prevalence, and environmental influences. Gastroenterology 2004;126:1504-17.

68. Okayasu I, Hatakeyama S, Yamada M, et al. A novel method in the induction of reliable experimental acute and chronic ulcerative colitis in mice. Gastroenterology 1990;98:694-702.

69. Vakil N, van Zanten SV, Kahrilas P, et al. Global Consensus Group. The Montreal definition and classification of gastroesophageal reflux disease: a global evidence-based consensus. Am J Gastroenterol 2006;101:1900-20; quiz 1943.

70. Malfertheiner P, Megraud F, O'Morain C, et al. Current concepts in the management of Helicobacter pylori infection: the Maastricht III Consensus Report. Gut 2007;56:772-81.

71. O'Grady JG, Alexander GJ, Hayllar KM, et al. Early indicators of prognosis in fulminant hepatic failure. Gastroenterology 1989;97:439-45.

72. Lo CM, Ngan H, Tso WK, et al. Randomized controlled trial of transarterial lipiodol chemoembolization for unresectable hepatocellular carcinoma. Hepatology 2002;35:1164-71.

73. Castéra L, Vergniol J, Foucher J, et al. Prospective comparison of transient elastography, Fibrotest, APRI, and liver biopsy for the assessment of fibrosis in chronic hepatitis C. Gastroenterology 2005:128:343-50.

74. Robert A. Cytoprotection by prostaglandins. Gastroenterology 1979;77(4 Pt 1):761-7.

75. Eaden JA, Abrams KR, Mayberry JF. The risk of colorectal cancer in ulcerative colitis: a meta-analysis. Gut 2001:48:526-35.

76. Bosch FX, Ribes J, Díaz M, et al. Primary liver cancer: worldwide incidence and trends. Gastroenterology 2004;127(5 Suppl 1):S5-16

77. Baggio LL, Drucker DJ. Biology of incretins: GLP-1 and GIP. Gastroenterology 2007;132:2131-57.

78. Bedossa $P$, Dargère $D$, Paradis V. Sampling variability of liver fibrosis in chronic hepatitis C. Hepatology 2003;38:1449-57.

79. Hurwitz H, Fehrenbacher L, Novotny W, et al. Bevacizumab plus irinotecan, fluorouracil, and leucovorin for metastatic colorectal cancer. N Engl J Med 2004;350:2335-42.

80. Choo QL, Kuo G, Weiner AJ, et al. Isolation of a cDNA clone derived from a blood-borne non-A, non-B viral hepatitis genome. Science 1989;244:359-62.

81. Pugh RN, Murray-Lyon IM, Dawson JL, et al. Transection of the oesophagus for bleeding oesophageal varices. $\mathrm{Br} J$ Surg 1973;60:646-9.

82. Manns MP, McHutchison JG, Gordon SC, et al. Peginterferon alfa-2b plus ribavirin compared with interferon alfa-2b plus ribavirin for initial treatment of chronic hepatitis C: a randomised trial. Lancet 2001;358:958-65.

83. Fried MW, Shiffman ML, Reddy KR, et al. Peginterferon alfa-2a plus ribavirin for chronic hepatitis $\mathrm{C}$ virus infection. $N$ Engl J Med 2002;347:975-82.

84. Llovet JM, Ricci S, Mazzaferro V, et al. SHARP Investigators Study Group. Sorafenib in advanced hepatocellular carcinoma. $N$ Engl $J$ Med 2008;359:378-90.
85. Kinzler KW, Vogelstein B. Lessons from hereditary colorectal cancer. Cell 1996;87:159-70.

86. Perna NT, Plunkett G III, Burland V, et al. Genome sequence of enterohaemorrhagic Escherichia coli O157:H7. Nature 2001;409:529-33.

87. Hugot JP, Chamaillard M, Zouali $\mathrm{H}$, et al. Association of NOD2 leucine-rich repeat variants with susceptibility to Crohn's disease. Nature 2001;411:599-603.

88. Tomb JF, White O, Kerlavage AR, et al. The complete genome sequence of the gastric pathogen Helicobacter pylori. Nature 1997;388:539-47.

89. Mazzaferro V, Regalia E, Doci R, et al. Liver transplantation for the treatment of small hepatocellular carcinomas in patients with cirrhosis. N Engl J Med 1996;334:693-9.

90. Kuo G, Choo QL, Alter HJ, et al. An assay for circulating antibodies to a major etiologic virus of human non-A, non-B hepatitis. Science 1989;244:362-4.

91. Ogura Y, Bonen DK, Inohara N, et al. A frameshift mutation in NOD2 associated with susceptibility to Crohn's disease. Nature 2001;411:603-6.

92. Parsonnet J, Friedman GD, Vandersteen DP, et al. Helicobacter pylori infection and the risk of gastric carcinoma. $N$ Engl $J$ Med 1991;325:1127-31.

93. Dixon MF, Genta RM, Yardley JH, et al. Classification and grading of gastritis. The updated Sydney System. International Workshop on the Histopathology of Gastritis, Houston 1994. Am J Surg Pathol 1996;20:1161-81.

94. Burris HA III, Moore MJ, Andersen J, et al. Improvements in survival and clinical benefit with gemcitabine as first-line therapy for patients with advanced pancreas cancer: a randomized trial. J Clin Oncol 1997;15:2403-13.

95. Cunningham $D$, Humblet $\mathrm{Y}$, Siena $\mathrm{S}$, et al. Cetuximab monotherapy and cetuximab plus irinotecan in irinotecan-refractory metastatic colorectal cancer. N Engl J Med 2004;351:337-45.

96. Hayashi T, Makino K, Ohnishi M, et al. Complete genome sequence of enterohemorrhagic Escherichia coli O157:H7 and genomic comparison with a laboratory strain K-12. DNA Res 2001;8:11-22.

97. Feder JN, Gnirke A, Thomas W, et al. A novel MHC class I-like gene is mutated in patients with hereditary haemochromatosis. Nat Genet 1996;13:399-408.

98. McHutchison JG, Gordon SC, Schiff ER, et al. Interferon alfa-2b alone or in combination with ribavirin as initial treatment for chronic hepatitis C. Hepatitis Interventional Therapy Group. N Engl J Med 1998;339:1485-92.

99. Groux H, O'Garra A, Bigler M, et al. A CD4+ T-cell subset inhibits antigen-specific T-cell responses and prevents colitis. Nature 1997;389:737-42.

100. Morin PJ, Sparks AB, Korinek V, et al. Activation of beta-catenin-Tcf signaling in colon cancer by mutations in beta-catenin or APC. Science 1997;275:1787-90.

101. Nataro JP, Kaper JB. Diarrheagenic Escherichia coli. Clin Microbio Rev 1998:11:142-201.

102. Boland CR, Thibodeau SN, Hamilton SR, et al. A National Cancer Institute Workshop on Microsatellite Instability for cancer detection and familial predisposition: development of international criteria for the determination of microsatellite instability in colorectal cancer. Cancer Res 1998;58:5248-57.

103. Llovet JM, Burroughs A, Bruix J. Hepatocellular carcinoma. Lancet 2003;362:1907-17.

104. Demetri GD, von Mehren M, Blanke CD, et al. Efficacy and safety of imatinib mesylate in advanced gastrointestinal stromal tumors. N Engl J Med 2002;347:472-80.

105. Winawer SJ, Zauber AG, Ho MN, et al. Prevention of colorectal cancer by colonoscopic polypectomy. The National Polyp Study Workgroup. N Engl J Med 1993;329:1977-81.

106. Aaltonen LA, Peltomäki P, Leach FS, et al. Clues to the pathogenesis of familial colorectal cancer. Science 1993;260:812-16.

107. Bombardier C, Laine L, Reicin A, et al. VIGOR Study Group. Comparison of upper gastrointestinal toxicity of rofecoxib and naproxen in patients with rheumatoid arthritis. VIGOR Study Group. N Engl J Med 2000;343:1520-8.

108. Thiebaut $\mathrm{F}$, Tsuruo $\mathrm{T}$, Hamada $\mathrm{H}$, et al. Cellular localization of the multidrug-resistance gene product $\mathrm{P}$-glycoprotein in normal human tissues. Proc Natl Acad Sci USA 1987:84:7735-8.

109. Fishel R, Lescoe MK, Rao MR, et al. The human mutator gene homolog MSH2 and its association with hereditary nonpolyposis colon cancer. Cell 1993;75:1027-38.

110. Angulo P. Nonalcoholic fatty liver disease. N Engl J Med 2002;346:1221-31. 
111. Targan SR, Hanauer SB, van Deventer SJ, et al. A short-term study of chimeric monoclonal antibody CA2 to tumor necrosis factor alpha for Crohn's disease. Crohn's Disease cA2 Study Group. N Engl J Med 1997;337:1029-35.

112. Stocker R, Yamamoto $\mathrm{Y}, \mathrm{McD}$ onagh $\mathrm{AF}$, et al. Bilirubin is an antioxidant of possible physiological importance. Science 1987;235:1043-6.

113. Podolsky DK. Inflammatory bowel disease. N Engl J Med 2002;347:417-29.

114. de Gramont A, Figer A, Seymour M, et al. Leucovorin and fluorouracil with or without oxaliplatin as first-line treatment in advanced colorectal cancer. J Clin Oncol 2000; 18:2938-47.

115. Hadziyannis SJ, Sette H Jr, Morgan TR, et al. PEGASYS International Study Group. Peginterferon-alpha2a and ribavirin combination therapy in chronic hepatitis $\mathrm{C}$ : a randomized study of treatment duration and ribavirin dose. Ann Intern Med 2004:140:346-55.

116. Mandel JS, Bond JH, Church TR, et al. Reducing mortality from colorectal cancer by screening for fecal occult blood. Minnesota Colon Cancer Control Study. N Engl J Med 1993;328:1365-71.

117. Saltz LB, Cox JV, Blanke C, et al. Irinotecan plus fluorouracil and leucovorin for metastatic colorectal cancer. Irinotecan Study Group. N Engl J Med 2000;343:905-14.

118. Uemura N, Okamoto S, Yamamoto S, et al. Helicobacter pylori infection and the development of gastric cancer. $N$ Engl J Med 2001;345:784-9.

119. Beasley RP, Hwang LY, Lin CC, et al. Hepatocellular carcinoma and hepatitis B virus. A prospective study of 22707 men in Taiwan. Lancet 1981;2:1129-33.
120. Koh HK. "Viral Hepatitis: The Secret Epidemic." Testimony before the Committee on Oversight and Governmental Reform, United States House of Representatives, 17 June 2010. http://www.hhs. gov/asl/testify/2010/06/t20100617b.html (accessed 23 Jan 2016).

121. Institute of Medicine (IOM). Hepatitis and liver cancer: a national strategy for prevention and control of hepatitis $B$ and $C$.

Washington DC: The National Academies Press, 2010:1-232.

122. Ananthakrishnan AN. Epidemiology and risk factors for IBD. Nat Rev Gastroenterol Hepatol 2015;12:205-17.

123. Edwards BK, Noone AM, Mariotto AB, et al. Annual Report to the Nation on the status of cancer, 1975-2010, featuring prevalence of comorbidity and impact on survival among persons with lung, colorectal, breast, or prostate cancer. Cancer 2014;120: 1290-314.

124. Loonen MP, Hage JJ, Kon M. Plastic Surgery Classics: characteristics of 50 top-cited articles in four Plastic Surgery Journals since 1946. Plast Reconstr Surg 2008;121:320e-7e.

125. Lowry $\mathrm{OH}$, Rosebrough $\mathrm{NJ}$, Farr $\mathrm{AL}$, et al. Protein measurement with the Folin phenol reagent. J Biol Chem 1951;193:265-75.

126. Danthi $\mathrm{N}, \mathrm{Wu} \mathrm{CO}$, Shi $\mathrm{P}$, et al. Percentile ranking and citation impact of a large cohort of National Heart, Lung, and Blood Institute-funded cardiovascular R01 grants. Circ Res 2014;114:600-6.

127. Fortin JM, Currie DJ. Big Science vs. Little Science: How Scientific Impact Scales with Funding. PLoS ONE 2013;8:e65263.

128. Long MT, Leszczynski A, Thompson KD, et al. Female authorship in major academic gastroenterology journals: a look over 20 years. Gastrointest Endosc 2015;81:1440-7.e3.

129. Tang X, Gong W, Yuan F, et al. Top-cited articles in digestive system disease from 1950 to 2013. J Gastroenterol Hepatol 2016;31:107-11. 


\section{APPENDIX 1}

Top-Cited Gastroenterology and Hepatology Articles Published in Gastroenterology and Hepatology Journals, identified by Category Search in the Web of Science ${ }^{\mathrm{TM}}$, Ranked from 1 to 50 (List A).

\begin{tabular}{|c|c|c|c|c|c|}
\hline Rank $^{c}$ & $\begin{array}{l}\text { Author, Year } \\
\text { [Reference] }\end{array}$ & Title (Journal) & Category & $\begin{array}{l}\text { Number of } \\
\text { citations }\end{array}$ & $\begin{array}{l}\text { Origin: First author's } \\
\text { organisation, location (country) }\end{array}$ \\
\hline 1 & $\begin{array}{l}\text { Bruix and } \\
\text { Sherman, } \\
2005^{25}\end{array}$ & $\begin{array}{l}\text { Management of hepatocellular } \\
\text { carcinoma (Hepatology) }\end{array}$ & $\begin{array}{l}\text { Practice } \\
\text { guideline }\end{array}$ & 2,959 & $\begin{array}{l}\text { University of Barcelona, Institut } \\
\text { d'Investigacions Biomèdiques } \\
\text { August Pi i Sunyer, Barcelona, } \\
\text { (Spain). }\end{array}$ \\
\hline 2 & $\begin{array}{l}\text { Knodell et al, } \\
1981^{26}\end{array}$ & $\begin{array}{l}\text { Formulation and application of a } \\
\text { numerical scoring system for } \\
\text { assessing histological activity in } \\
\text { asymptomatic chronic active } \\
\text { hepatitis. (Hepatology). }\end{array}$ & Research & 2,890 & $\begin{array}{l}\text { Gastroenterology Section, Veterans } \\
\text { Administration Medical Center, } \\
\text { Minneapolis, Minnesota, (United } \\
\text { States). }\end{array}$ \\
\hline 3 & $\begin{array}{l}\text { Ishak et al, } \\
1995^{27}\end{array}$ & $\begin{array}{l}\text { Histological grading and staging } \\
\text { of chronic hepatitis. (Journal of } \\
\text { Hepatology). }\end{array}$ & Article & 2,603 & $\begin{array}{l}\text { Armed Forces Institute of } \\
\text { Pathology, Washington, (United } \\
\text { States). }\end{array}$ \\
\hline 4 & $\begin{array}{l}\text { Bruix et al, } \\
2001^{28}\end{array}$ & $\begin{array}{l}\text { Clinical management of } \\
\text { hepatocellular carcinoma. } \\
\text { Conclusions of the } \\
\text { Barcelona-2000 EASL } \\
\text { conference. European } \\
\text { Association for the Study of the } \\
\text { Liver ( Journal of Hepatology). }\end{array}$ & Article & 2,467 & $\begin{array}{l}\text { Liver Unit, Digestive Disease } \\
\text { Institute, Hospital Clinic, IDIBAPS, } \\
\text { Barcelona, Catalonia, (Spain). }\end{array}$ \\
\hline 5 & $\begin{array}{l}\text { Best et al, } \\
1976^{29}\end{array}$ & $\begin{array}{l}\text { Development of a Crohn's } \\
\text { disease activity index. National } \\
\text { Cooperative Crohn's Disease } \\
\text { Study (Gastroenterology) }\end{array}$ & Research & 2,263 & $\begin{array}{l}\text { University of Colorado Medical } \\
\text { Center, Denver, Colorado, (United } \\
\text { States) }\end{array}$ \\
\hline 6 & $\begin{array}{l}\text { Kleiner et al, } \\
2005^{30}\end{array}$ & $\begin{array}{l}\text { Design and validation of a } \\
\text { histological scoring system for } \\
\text { nonalcoholic fatty liver disease. } \\
\text { (Hepatology) }\end{array}$ & Research & 2,222 & $\begin{array}{l}\text { Laboratory of Pathology, National } \\
\text { Cancer Institute, Bethesda, MD, } \\
\text { (United States) }\end{array}$ \\
\hline 7 & $\begin{array}{l}\text { Desmet et al, } \\
1994^{31}\end{array}$ & $\begin{array}{l}\text { Classification of chronic hepatitis: } \\
\text { diagnosis, grading and staging. } \\
\text { (Hepatology). }\end{array}$ & Review & 2038 & $\begin{array}{l}\text { Department of Pathology, Catholic } \\
\text { University of Leuven, (Belgium). }\end{array}$ \\
\hline 8 & $\begin{array}{l}\text { El-Serag and } \\
\text { Rudolph, } \\
2007^{32}\end{array}$ & $\begin{array}{l}\text { Hepatocellular carcinoma: } \\
\text { epidemiology and molecular } \\
\text { carcinogenesis. } \\
\text { (Gastroenterology). }\end{array}$ & Review & 2,028 & $\begin{array}{l}\text { Michael E. DeBakey Veterans } \\
\text { Administration Medical Center and } \\
\text { Baylor College of Medicine, } \\
\text { Houston, Texas, (United States) }\end{array}$ \\
\hline 9 & $\begin{array}{l}\text { Eberhart et al, } \\
1994^{33}\end{array}$ & $\begin{array}{l}\text { Up-regulation of cyclooxygenase } \\
2 \text { gene expression in human } \\
\text { colorectal adenomas and } \\
\text { adenocarcinomas. } \\
\text { (Gastroenterology) }\end{array}$ & Research & 1,929 & $\begin{array}{l}\text { Vanderbilt University Medical } \\
\text { Center, Nashville, Tennessee } \\
\text { (United States). }\end{array}$ \\
\hline 10 & $\begin{array}{l}\text { Kamath et al, } \\
2001^{34}\end{array}$ & $\begin{array}{l}\text { A model to predict survival in } \\
\text { patients with end-stage liver } \\
\text { disease (Hepatology). }\end{array}$ & Research & 1,916 & $\begin{array}{l}\text { Division of Gastroenterology and } \\
\text { Hepatology, Mayo Clinic and } \\
\text { Foundation, Rochester, (United } \\
\text { States). }\end{array}$ \\
\hline 11 & $\begin{array}{l}\text { Day and } \\
\text { James, } 1998^{35}\end{array}$ & $\begin{array}{l}\text { Steatohepatitis: a tale of two } \\
\text { "hits"? (Gastroenterology) }\end{array}$ & Article & 1,808 & $\begin{array}{l}\text { Centre for Liver Research } \\
\text { Newcastle Upon Tyne, (United } \\
\text { Kingdom) }\end{array}$ \\
\hline 12 & $\begin{array}{l}\text { Bedossa and } \\
\text { Poynard, } \\
1996^{36}\end{array}$ & $\begin{array}{l}\text { An algorithm for the grading of } \\
\text { activity in chronic hepatitis C. The } \\
\text { METAVIR Cooperative Study } \\
\text { Group. (Hepatology). }\end{array}$ & Research & 1,783 & $\begin{array}{l}\text { Service d'Anatomie Pathologique, } \\
\text { Hôpital de Bicêtre, Le Kremlin- } \\
\text { Bicêtre, (France). }\end{array}$ \\
\hline 13 & $\begin{array}{l}\text { Robert et al, } \\
1979^{37}\end{array}$ & $\begin{array}{l}\text { Cytoprotection by prostaglandins } \\
\text { in rats. Prevention of gastric }\end{array}$ & Research & 1,722 & $\begin{array}{l}\text { The Upjohn Company, Kalamazoo, } \\
\text { Michigan (United States). }\end{array}$ \\
\hline
\end{tabular}


Continued

\begin{tabular}{|c|c|c|c|c|c|}
\hline Rank $^{c}$ & $\begin{array}{l}\text { Author, Year } \\
\text { [Reference] }\end{array}$ & Title (Journal) & Category & $\begin{array}{l}\text { Number of } \\
\text { citations }\end{array}$ & $\begin{array}{l}\text { Origin: First author's } \\
\text { organisation, location (country) }\end{array}$ \\
\hline & & $\begin{array}{l}\text { necrosis produced by alcohol, } \mathrm{HCl} \text {, } \\
\mathrm{NaOH} \text {, hypertonic } \mathrm{NaCl} \text {, and } \\
\text { thermal injury. (Gastroenterology). }\end{array}$ & & & \\
\hline 14 & $\begin{array}{l}\text { Brunt et al, } \\
1999^{38}\end{array}$ & $\begin{array}{l}\text { Nonalcoholic steatohepatitis: a } \\
\text { proposal for grading and staging } \\
\text { the histological lesions (American } \\
\text { Journal of Gastroenterology). }\end{array}$ & Review & 1,681 & $\begin{array}{l}\text { Department of Pathology, Saint } \\
\text { Louis University School of } \\
\text { Medicine, Missouri, (United States). }\end{array}$ \\
\hline 15 & $\begin{array}{l}\text { Bruix et al, } \\
2011^{39}\end{array}$ & $\begin{array}{l}\text { Management of hepatocellular } \\
\text { carcinoma: an update. } \\
\text { (Hepatology). }\end{array}$ & $\begin{array}{l}\text { Practice } \\
\text { guideline }\end{array}$ & 1,642 & $\begin{array}{l}\text { Barcelona Clinic Liver Cancer } \\
\text { (BCLC) Group, Liver Unit, Hospital } \\
\text { Clínic, University of Barcelona, } \\
\text { Barcelona, (Spain). }\end{array}$ \\
\hline 16 & $\begin{array}{l}\text { Longstreth } \\
\text { et al, } 2006^{40}\end{array}$ & $\begin{array}{l}\text { Functional bowel disorders } \\
\text { (Gastroenterology). }\end{array}$ & $\begin{array}{l}\text { Practice } \\
\text { guidelines }\end{array}$ & 1,616 & $\begin{array}{l}\text { Kaiser Permanente Medical Care } \\
\text { Program, San Diego, California, } \\
\text { (United States). }\end{array}$ \\
\hline 17 & $\begin{array}{l}\text { Ghany et al, } \\
2009^{41}\end{array}$ & $\begin{array}{l}\text { Diagnosis, management, and } \\
\text { treatment of hepatitis C: an } \\
\text { update. (Hepatology). }\end{array}$ & $\begin{array}{l}\text { Practical } \\
\text { guideline }\end{array}$ & 1,603 & $\begin{array}{l}\text { National Institute of Diabetes and } \\
\text { Digestive and Kidney Diseases, } \\
\text { National Institutes of Health, } \\
\text { Bethesda, MD (United States). }\end{array}$ \\
\hline 18 & $\begin{array}{l}\text { Matteoni et al, } \\
1998^{42}\end{array}$ & $\begin{array}{l}\text { Nonalcoholic fatty liver disease: a } \\
\text { spectrum of clinical and } \\
\text { pathological severity. } \\
\text { (Gastroenterology). }\end{array}$ & Research & 1,565 & $\begin{array}{l}\text { University Hospitals of Cleveland, } \\
\text { Department of Medicine, } \\
\text { Cleveland, Ohio, USA. (United } \\
\text { States) }\end{array}$ \\
\hline 19 & $\begin{array}{l}\text { Cotton et al, } \\
1991^{43}\end{array}$ & $\begin{array}{l}\text { Endoscopic sphincterotomy } \\
\text { complications and their } \\
\text { management: an attempt at } \\
\text { consensus. (Gastrointestinal } \\
\text { Endoscopy). }\end{array}$ & Review & 1,515 & $\begin{array}{l}\text { Department of Medicine, Duke } \\
\text { University Medical Center, Durham, } \\
\text { North Carolina (United States). }\end{array}$ \\
\hline 20 & $\begin{array}{l}\text { Lok and } \\
\text { McMahon, } \\
2007^{44}\end{array}$ & Chronic hepatitis B (Hepatology). & $\begin{array}{l}\text { Practical } \\
\text { guideline }\end{array}$ & 1,511 & $\begin{array}{l}\text { University of Michigan Medical } \\
\text { Center, Ann Arbor, MI (United } \\
\text { States). }\end{array}$ \\
\hline 21 & $\begin{array}{l}\text { Shay et al, } \\
1945^{45}\end{array}$ & $\begin{array}{l}\text { A simple method for the uniform } \\
\text { production of gastric ulceration in } \\
\text { the rat (Gastroenterology). }\end{array}$ & Research & 1,455 & $\begin{array}{l}\text { Research Institute Temple } \\
\text { University, School of Medicine, } \\
\text { Philadelphia (United States). }\end{array}$ \\
\hline 22 & $\begin{array}{l}\text { Fiocchi, } \\
1998^{46}\end{array}$ & $\begin{array}{l}\text { Inflammatory bowel disease: } \\
\text { etiology and pathogenesis. } \\
\text { (Gastroenterology). }\end{array}$ & Review & 1,443 & $\begin{array}{l}\text { University Hospitals of Cleveland, } \\
\text { Case Western Reserve University } \\
\text { School of Medicine, Ohio, (United } \\
\text { States). }\end{array}$ \\
\hline 23 & $\begin{array}{l}\text { Winawer et al, } \\
1997^{47}\end{array}$ & $\begin{array}{l}\text { Colorectal cancer screening: } \\
\text { clinical guidelines and rationale } \\
\text { (Gastroenterology). }\end{array}$ & $\begin{array}{l}\text { Practice } \\
\text { guideline }\end{array}$ & 1,388 & $\begin{array}{l}\text { Gastroenterology and Nutrition } \\
\text { Service Memorial Sloan-Kettering } \\
\text { Cancer Center, New York, (United } \\
\text { States). }\end{array}$ \\
\hline \multirow[t]{2}{*}{24} & $\begin{array}{l}\text { Browning et al, } \\
2004^{48}\end{array}$ & $\begin{array}{l}\text { Prevalence of hepatic steatosis in } \\
\text { an urban population in the United } \\
\text { States: impact of ethnicity } \\
\text { (Hepatology). }\end{array}$ & Research & 1,373 & $\begin{array}{l}\text { Department of Internal Medicine, } \\
\text { The University of Texas } \\
\text { Southwestern Medical Center at } \\
\text { Dallas, Dallas, Texas (United } \\
\text { States). }\end{array}$ \\
\hline & $\begin{array}{l}\text { Vasen et al, } \\
1991^{49}\end{array}$ & $\begin{array}{l}\text { The International Collaborative } \\
\text { Group on Hereditary Non- } \\
\text { Polyposis Colorectal Cancer } \\
\text { (ICG-HNPCC). (Diseases of the } \\
\text { Colon \& Rectum) }\end{array}$ & Article & 1,373 & $\begin{array}{l}\text { The Netherlands Foundation for the } \\
\text { Detection of Hereditary Tumours, } \\
\text { Utrecht/Leiden Centraal, The } \\
\text { Netherlands. }\end{array}$ \\
\hline 25 & $\begin{array}{l}\text { Winawer et al, } \\
2003^{50}\end{array}$ & $\begin{array}{l}\text { Colorectal cancer screening and } \\
\text { surveillance: clinical guidelines } \\
\text { and rationale-Update based on } \\
\text { new evidence (Gastroenterology). }\end{array}$ & $\begin{array}{l}\text { Practice } \\
\text { guidelines }\end{array}$ & 1,348 & $\begin{array}{l}\text { Memorial Sloan-Kettering Cancer } \\
\text { Center, and Weill Medical College } \\
\text { of Cornell University, New York, } \\
\text { (United States). }\end{array}$ \\
\hline 26 & $\begin{array}{l}\text { Hidalgo et al, } \\
1989^{51}\end{array}$ & $\begin{array}{l}\text { Characterization of the human } \\
\text { colon carcinoma cell line (Caco-2) } \\
\text { as a model system for intestinal }\end{array}$ & Research & 1,345 & $\begin{array}{l}\text { Department of Pharmaceutical } \\
\text { Chemistry, University of Kansas, } \\
\text { (United States) }\end{array}$ \\
\hline
\end{tabular}




\begin{tabular}{|c|c|c|c|c|c|}
\hline Rank $^{c}$ & $\begin{array}{l}\text { Author, Year } \\
\text { [Reference] }\end{array}$ & Title (Journal) & Category & $\begin{array}{l}\text { Number of } \\
\text { citations }\end{array}$ & $\begin{array}{l}\text { Origin: First author's } \\
\text { organisation, location (country) }\end{array}$ \\
\hline & & $\begin{array}{l}\text { epithelial permeability. } \\
\text { (Gastroenterology) }\end{array}$ & & & \\
\hline 27 & $\begin{array}{l}\text { Llovet and } \\
\text { Bruix, } 2003^{52}\end{array}$ & $\begin{array}{l}\text { Systematic review of randomized } \\
\text { trials for unresectable } \\
\text { hepatocellular carcinoma: } \\
\text { Chemoembolization improves } \\
\text { survival. (Hepatology). }\end{array}$ & Review & 1,335 & $\begin{array}{l}\text { Barcelona-Clínic Liver Cancer } \\
\text { Group, Institut d'Investigacions } \\
\text { Biomèdiques August Pi i Sunyer, } \\
\text { Hospital Clínic, Catalonia, (Spain). }\end{array}$ \\
\hline 28 & Marsh, $1992^{53}$ & $\begin{array}{l}\text { Gluten, major histocompatibility } \\
\text { complex, and the small intestine. } \\
\text { A molecular and immunobiologic } \\
\text { approach to the spectrum of } \\
\text { gluten sensitivity ('celiac sprue') } \\
\text { (Gastroenterology). }\end{array}$ & Article & 1,323 & $\begin{array}{l}\text { University Department of Medicine, } \\
\text { Manchester University School of } \\
\text { Medicine, (United Kingdom) }\end{array}$ \\
\hline 29 & $\begin{array}{l}\text { Meng et al, } \\
2007^{54}\end{array}$ & $\begin{array}{l}\text { MicroRNA-21 regulates } \\
\text { expression of the PTEN tumor } \\
\text { suppressor gene in human } \\
\text { hepatocellular cancer. } \\
\text { (Gastroenterology). }\end{array}$ & Research & 1,307 & $\begin{array}{l}\text { Scott and White Clinic, Texas A\&M } \\
\text { University System Health Science } \\
\text { Center College of Medicine, } \\
\text { Temple, Texas (United States). }\end{array}$ \\
\hline \multirow[t]{2}{*}{30} & $\begin{array}{l}\text { Vasen et al, } \\
1999^{55}\end{array}$ & $\begin{array}{l}\text { New clinical criteria for hereditary } \\
\text { nonpolyposis colorectal cancer } \\
\text { (HNPCC, Lynch syndrome) } \\
\text { proposed by the International } \\
\text { Collaborative group on HNPCC. } \\
\text { (Gastroenterology). }\end{array}$ & $\begin{array}{l}\text { Practical } \\
\text { guidelines }\end{array}$ & 1,280 & $\begin{array}{l}\text { The Netherlands Foundation for the } \\
\text { Detection of Hereditary Tumours, } \\
\text { Leiden, (The Netherlands). }\end{array}$ \\
\hline & $\begin{array}{l}\text { Drossman } \\
\text { et al, } 1993^{56}\end{array}$ & $\begin{array}{l}\text { U.S. householder survey of } \\
\text { functional gastrointestinal } \\
\text { disorders. Prevalence, } \\
\text { sociodemography, and health } \\
\text { impact. (Digestive Diseases and } \\
\text { Sciences) }\end{array}$ & Research & 1,280 & $\begin{array}{l}\text { University of North Carolina, } \\
\text { Division of Digestive Diseases, } \\
\text { Chapel Hill (United States) }\end{array}$ \\
\hline 31 & $\begin{array}{l}\text { Locke et al, } \\
1997^{57}\end{array}$ & $\begin{array}{l}\text { Prevalence and clinical spectrum } \\
\text { of gastroesophageal reflux: a } \\
\text { population-based study in } \\
\text { Olmsted County, Minnesota. } \\
\text { (Gastroenterology). }\end{array}$ & Research & 1,278 & $\begin{array}{l}\text { Department of Health Sciences } \\
\text { Research, Mayo Clinic and Mayo } \\
\text { Foundation, Rochester, Minnesota, } \\
\text { (United States). }\end{array}$ \\
\hline 32 & $\begin{array}{l}\text { Wai et al, } \\
2003^{58}\end{array}$ & $\begin{array}{l}\text { A simple noninvasive index can } \\
\text { predict both significant fibrosis } \\
\text { and cirrhosis in patients with } \\
\text { chronic hepatitis C. (Hepatology). }\end{array}$ & Research & 1,232 & $\begin{array}{l}\text { Division of Gastroenterology, } \\
\text { University of Michigan Medical } \\
\text { School, Ann Arbor, MI (United } \\
\text { States). }\end{array}$ \\
\hline 33 & $\begin{array}{l}\text { Strader et al, } \\
2004^{59}\end{array}$ & $\begin{array}{l}\text { Diagnosis, management, and } \\
\text { treatment of hepatitis } \\
\text { C. (Hepatology).. }\end{array}$ & $\begin{array}{l}\text { Practical } \\
\text { guideline }\end{array}$ & 1,212 & $\begin{array}{l}\text { Fletcher Allen Health Care } \\
\text { University of Vermont College of } \\
\text { Medicine, Burlington, VA, (United } \\
\text { States). }\end{array}$ \\
\hline 34 & $\begin{array}{l}\text { Morris et al, } \\
1989^{60}\end{array}$ & $\begin{array}{l}\text { Hapten-induced model of chronic } \\
\text { inflammation and ulceration in the } \\
\text { rat colon. (Gastroenterology). }\end{array}$ & Research & 1,197 & $\begin{array}{l}\text { Queen's University, Kingston, } \\
\text { Ontario, (Canada). }\end{array}$ \\
\hline 35 & $\begin{array}{l}\text { Krawisz et al, } \\
1984^{61}\end{array}$ & $\begin{array}{l}\text { Quantitative assay for acute } \\
\text { intestinal inflammation based on } \\
\text { myeloperoxidase activity. } \\
\text { Assessment of inflammation in rat } \\
\text { and hamster models. } \\
\text { (Gastroenterology). }\end{array}$ & Research & 1,195 & $\begin{array}{l}\text { The Jewish Hospital of St. Louis at } \\
\text { Washington University School of } \\
\text { Medicine, St. Louis, Missouri } \\
\text { (United States). }\end{array}$ \\
\hline 36 & $\begin{array}{l}\text { Marchesini } \\
\text { et al, } 2003^{62}\end{array}$ & $\begin{array}{l}\text { Nonalcoholic fatty liver, } \\
\text { steatohepatitis, and the metabolic } \\
\text { syndrome. (Hepatology). }\end{array}$ & Research & 1,193 & $\begin{array}{l}\text { Unit of Metabolic Diseases and } \\
\text { Department of Internal Medicine, } \\
\text { Alma Mater Studiorum University of } \\
\text { Bologna, Bologna, (Italy). }\end{array}$ \\
\hline
\end{tabular}


Continued

\begin{tabular}{|c|c|c|c|c|c|}
\hline Rank $^{c}$ & $\begin{array}{l}\text { Author, Year } \\
\text { [Reference] }\end{array}$ & Title (Journal) & Category & $\begin{array}{l}\text { Number of } \\
\text { citations }\end{array}$ & $\begin{array}{l}\text { Origin: First author's } \\
\text { organisation, location (country) }\end{array}$ \\
\hline \multirow[t]{2}{*}{37} & $\begin{array}{l}\text { Llovet et al, } \\
1999^{63}\end{array}$ & $\begin{array}{l}\text { Prognosis of hepatocellular } \\
\text { carcinoma: the BCLC staging } \\
\text { classification. (Seminars in Liver } \\
\text { Disease). }\end{array}$ & Review & 1,177 & $\begin{array}{l}\text { Institut d'Investigacions Biomèdiques } \\
\text { August Pi i Sunyer (IDIBAPS), } \\
\text { Hospital Clinic, University of } \\
\text { Barcelona, Catalonia, (Spain). }\end{array}$ \\
\hline & $\begin{array}{l}\text { Lavanchy, } \\
2004^{64}\end{array}$ & $\begin{array}{l}\text { Hepatitis B virus epidemiology, } \\
\text { disease burden, treatment, and } \\
\text { current and emerging prevention } \\
\text { and control measures. (Journal of } \\
\text { Viral Hepatitis) }\end{array}$ & Review & 1,177 & $\begin{array}{l}\text { World Health Organization, } \\
\text { Communicable Disease } \\
\text { Surveillance and Response, } \\
\text { Geneva, (Switzerland). }\end{array}$ \\
\hline 38 & $\begin{array}{l}\text { Granger et al, } \\
1981^{65}\end{array}$ & $\begin{array}{l}\text { Superoxide radicals in feline } \\
\text { intestinal ischemia. } \\
\text { (Gastroenterology). }\end{array}$ & Research & 1,176 & $\begin{array}{l}\text { University of South Alabama, } \\
\text { Mobile, Alabama (United States). }\end{array}$ \\
\hline 39 & $\begin{array}{l}\text { Lok and } \\
\text { McMahon, } \\
2009^{66}\end{array}$ & $\begin{array}{l}\text { Chronic hepatitis B: update } 2009 . \\
\text { (Hepatology). }\end{array}$ & $\begin{array}{l}\text { Practical } \\
\text { guideline }\end{array}$ & 1,168 & $\begin{array}{l}\text { University of Michigan Medical } \\
\text { Center, Ann Arbor, MI (United } \\
\text { States). }\end{array}$ \\
\hline 40 & Loftus, $2004^{67}$ & $\begin{array}{l}\text { Clinical epidemiology of } \\
\text { inflammatory bowel disease: } \\
\text { Incidence, prevalence, and } \\
\text { environmental influences. } \\
\text { (Gastroenterology). }\end{array}$ & Review & 1,161 & $\begin{array}{l}\text { Division of Gastroenterology and } \\
\text { Hepatology, Mayo Clinic, } \\
\text { Rochester, Minnesota (United } \\
\text { States). }\end{array}$ \\
\hline 41 & $\begin{array}{l}\text { Okayasu et al, } \\
1990^{68}\end{array}$ & $\begin{array}{l}\text { A novel method in the induction } \\
\text { of reliable experimental acute and } \\
\text { chronic ulcerative colitis in mice. } \\
\text { (Gastroenterology). }\end{array}$ & Research & 1,158 & $\begin{array}{l}\text { Department of Pathology, School of } \\
\text { Medicine, Tokyo Medical and } \\
\text { Dental University, (Japan.) }\end{array}$ \\
\hline 42 & $\begin{array}{l}\text { Vakil et al, } \\
2006^{69}\end{array}$ & $\begin{array}{l}\text { The Montreal definition and } \\
\text { classification of gastroesophageal } \\
\text { reflux disease: a global } \\
\text { evidence-based consensus } \\
\text { (American Journal of } \\
\text { Gastroenterology). }\end{array}$ & $\begin{array}{l}\text { Practical } \\
\text { guideline }\end{array}$ & 1,145 & $\begin{array}{l}\text { University of Wisconsin School of } \\
\text { Medicine and Public Health, } \\
\text { Madison, Wisconsin, (United } \\
\text { States). }\end{array}$ \\
\hline 43 & $\begin{array}{l}\text { Malfertheiner } \\
\text { et al, } 2007^{70}\end{array}$ & $\begin{array}{l}\text { Current concepts in the } \\
\text { management of Helicobacter } \\
\text { pylori infection: the Maastricht III } \\
\text { Consensus Report. (Gut) }\end{array}$ & $\begin{array}{l}\text { Practical } \\
\text { guideline }\end{array}$ & 1,143 & $\begin{array}{l}\text { Universitat Magdeburg, } \\
\text { Medizinische Fakultat, Zentrum fu? } \\
\text { r Innere Medizin, Klinik fu?r } \\
\text { Gastroenterologie, Hepatologie und } \\
\text { Infektiologie, Leipziger Magdeburg, } \\
\text { (Germany) }\end{array}$ \\
\hline 44 & $\begin{array}{l}\text { O'Grady } \\
\text { et al, } 1989^{71}\end{array}$ & $\begin{array}{l}\text { Early indicators of prognosis in } \\
\text { fulminant hepatic failure. } \\
\text { (Gastroenterology). }\end{array}$ & Research & 1,132 & $\begin{array}{l}\text { Liver Unit, King's College School of } \\
\text { Medicine, London, (United } \\
\text { Kingdom). }\end{array}$ \\
\hline 45 & $\begin{array}{l}\text { Lo et al, } \\
2002^{72}\end{array}$ & $\begin{array}{l}\text { Randomized controlled trial of } \\
\text { transarterial lipiodol } \\
\text { chemoembolization for } \\
\text { unresectable hepatocellular } \\
\text { carcinoma. (Hepatology). }\end{array}$ & Research & 1,122 & $\begin{array}{l}\text { Center for the Study of Liver } \\
\text { Disease, University of Hong Kong } \\
\text { Medical Center, Queen Mary } \\
\text { Hospital, Hong Kong, (China). }\end{array}$ \\
\hline 46 & $\begin{array}{l}\text { Castéra et al, } \\
2005^{73}\end{array}$ & $\begin{array}{l}\text { Prospective comparison of } \\
\text { transient elastography, Fibrotest, } \\
\text { APRI, and liver biopsy for the } \\
\text { assessment of fibrosis in chronic } \\
\text { hepatitis C. (Gastroenterology). }\end{array}$ & Research & 1,101 & $\begin{array}{l}\text { Service } \\
\text { d'Hépato-gastroentérologie, Hôpital } \\
\text { Haut Lévêque, C. H. U. Bordeaux, } \\
\text { Pessac, (France). }\end{array}$ \\
\hline 47 & Robert, $1979^{74}$ & $\begin{array}{l}\text { Cytoprotection by prostaglandins. } \\
\text { (Gastroenterology). }\end{array}$ & Article & 1,096 & $\begin{array}{l}\text { Department of Experimental } \\
\text { Biology, The Upjohn Company, } \\
\text { Kalamazoo, Michigan, (United } \\
\text { States). }\end{array}$ \\
\hline 48 & $\begin{array}{l}\text { Eaden et al, } \\
2001^{75}\end{array}$ & $\begin{array}{l}\text { The risk of colorectal cancer in } \\
\text { ulcerative colitis: a meta-analysis } \\
\text { (Gut). }\end{array}$ & Review & 1,081 & $\begin{array}{l}\text { Gastrointestinal Research Unit, } \\
\text { Leicester General Hospital, } \\
\text { Leicester (United Kingdom). }\end{array}$ \\
\hline 49 & $\begin{array}{l}\text { Bosch et al, } \\
2004^{76}\end{array}$ & & Review & 1,071 & $\begin{array}{l}\text { IDIBELL Institut Català d'Oncologia, } \\
\text { Avda. Barcelona, (Spain). }\end{array}$ \\
\hline
\end{tabular}


Continued

\begin{tabular}{|c|c|c|c|c|c|}
\hline Rank $^{c}$ & $\begin{array}{l}\text { Author, Year } \\
\text { [Reference] }\end{array}$ & Title (Journal) & Category & $\begin{array}{l}\text { Number of } \\
\text { citations }\end{array}$ & $\begin{array}{l}\text { Origin: First author's } \\
\text { organisation, location (country) }\end{array}$ \\
\hline \multirow{3}{*}{50} & & $\begin{array}{l}\text { Primary liver cancer: worldwide } \\
\text { incidence and trends } \\
\text { (Gastroenterology). }\end{array}$ & & & \\
\hline & $\begin{array}{l}\text { Baggio and } \\
\text { Drucker, } \\
2007^{77}\end{array}$ & $\begin{array}{l}\text { Biology of incretins: GLP-1 and } \\
\text { GIP (Gastroenterology). }\end{array}$ & Review & 1,049 & $\begin{array}{l}\text { Best Diabetes Centre, University of } \\
\text { Toronto, Toronto, Ontario, Canada. }\end{array}$ \\
\hline & $\begin{array}{l}\text { Bedossa et al, } \\
2003^{78}\end{array}$ & $\begin{array}{l}\text { Sampling variability of liver } \\
\text { fibrosis in chronic hepatitis } \\
\text { C. (Hepatology). }\end{array}$ & Research & 1,049 & $\begin{array}{l}\text { Service d'Anatomie Pathologique, } \\
\text { Hôpital Bicêtre, Le Kremlin- Bicêtre, } \\
\text { (France). }\end{array}$ \\
\hline
\end{tabular}

\section{APPENDIX 2}

Top-Cited Gastroenterology and Hepatology Articles Published Across All Journals Listed in the Web of Science ${ }^{\mathrm{TM}}$, Identified by Keyword Search, Ranked From 1 to 50 (List B).

\begin{tabular}{|c|c|c|c|c|c|}
\hline Rank $^{c}$ & $\begin{array}{l}\text { Author, Year } \\
\text { [Reference] }\end{array}$ & Title (Journal) & Category & $\begin{array}{l}\text { Number of } \\
\text { citations }\end{array}$ & $\begin{array}{l}\text { Origin: First author's } \\
\text { organisation, location (country) }\end{array}$ \\
\hline 1 & $\begin{array}{l}\text { Hurwitz et al, } \\
2004^{79}\end{array}$ & $\begin{array}{l}\text { Bevacizumab plus irinotecan, } \\
\text { fluorouracil, and leucovorin } \\
\text { formetastatic colorectal cancer (New } \\
\text { England Journal of Medicine). }\end{array}$ & Research & 5,500 & $\begin{array}{l}\text { Duke University Medical Center, } \\
\text { Durham, North Carolina, (United } \\
\text { States). }\end{array}$ \\
\hline 2 & $\begin{array}{l}\text { Choo et al, } \\
1989^{80}\end{array}$ & $\begin{array}{l}\text { Isolation of a cDNA clone derived } \\
\text { from a blood-borne non-A, non-B viral } \\
\text { hepatitis genome (Science). }\end{array}$ & Research & 5,227 & $\begin{array}{l}\text { Chiron Corporation, Emeryville, } \\
\text { California, (United States) }\end{array}$ \\
\hline 3 & $\begin{array}{l}\text { Pugh et al, } \\
1973^{81}\end{array}$ & $\begin{array}{l}\text { Transection of the oesophagus for } \\
\text { bleeding oesophageal varices. (British } \\
\text { Journal of Surgery) }\end{array}$ & Research & 4,630 & $\begin{array}{l}\text { King's College Hospital and } \\
\text { Medical School, London, (United } \\
\text { Kingdom). }\end{array}$ \\
\hline 4 & $\begin{array}{l}\text { Manns et al, } \\
2001^{82}\end{array}$ & $\begin{array}{l}\text { Peginterferon alfa-2b plus ribavirin } \\
\text { compared with interferon alfa- } 2 \mathrm{~b} \text { plus } \\
\text { ribavirin for initial treatment of chronic } \\
\text { hepatitis C: a randomised trial } \\
\text { (Lancet). }\end{array}$ & Research & 4,438 & $\begin{array}{l}\text { Division of Gastroenterology and } \\
\text { Hepatology, Medical School of } \\
\text { Hannover, Hannover, (Germany). }\end{array}$ \\
\hline 5 & $\begin{array}{l}\text { Fried et al, } \\
2002^{83}\end{array}$ & $\begin{array}{l}\text { Peginterferon alfa-2a plus ribavirin for } \\
\text { chronic hepatitis C virus infection. } \\
\text { (New England Journal of Medicine). }\end{array}$ & Research & 4,363 & $\begin{array}{l}\text { University of North Carolina, } \\
\text { Chapel Hill (United States). }\end{array}$ \\
\hline 6 & $\begin{array}{l}\text { Llovet et al, } \\
2008^{84}\end{array}$ & $\begin{array}{l}\text { Sorafenib in advanced hepatocellular } \\
\text { carcinoma. (New England Journal of } \\
\text { Medicine). }\end{array}$ & Research & 3,355 & $\begin{array}{l}\text { Barcelona Clínic Liver Cancer } \\
\text { Group, Liver Unit, Barcelona, } \\
\text { (Spain). }\end{array}$ \\
\hline 7 & $\begin{array}{l}\text { Kinzler and } \\
\text { Vogelstein, } \\
1996^{85}\end{array}$ & $\begin{array}{l}\text { Lessons from hereditary colorectal } \\
\text { cancer (Cell). }\end{array}$ & Review & 3,325 & $\begin{array}{l}\text { The Johns Hopkins Oncology } \\
\text { Center, Baltimore, Maryland } \\
\text { (United States). }\end{array}$ \\
\hline 8 & $\begin{array}{l}\text { Perna et al, } \\
2001^{86}\end{array}$ & $\begin{array}{l}\text { Genome sequence of } \\
\text { enterohaemorrhagic Escherichia coli } \\
\text { O157:H7. (Nature). }\end{array}$ & Research & 3,306 & $\begin{array}{l}\text { Genome Center of Wisconsin, } \\
\text { University of Wisconsin, Madison, } \\
\text { (United States) }\end{array}$ \\
\hline 9 & $\begin{array}{l}\text { Hugot et al, } \\
2001^{87}\end{array}$ & $\begin{array}{l}\text { Association of NOD2 leucine-rich } \\
\text { repeat variants with susceptibility to } \\
\text { Crohn's disease. (Nature). }\end{array}$ & Research & 3,185 & $\begin{array}{l}\text { Fondation Jean Dausset CEPH, } \\
\text { Paris, (France). }\end{array}$ \\
\hline 10 & $\begin{array}{l}\text { Tomb et al, } \\
1997^{88}\end{array}$ & $\begin{array}{l}\text { The complete genome sequence of } \\
\text { the gastric pathogen Helicobacter } \\
\text { pylori. (Nature). }\end{array}$ & Research & 3,173 & $\begin{array}{l}\text { Institute for Genomic Research, } \\
\text { Rockville, Maryland 20850, (United } \\
\text { Stats). }\end{array}$ \\
\hline 11 & $\begin{array}{l}\text { Mazzaferro } \\
\text { et al, } 1996^{89}\end{array}$ & $\begin{array}{l}\text { Liver transplantation for the treatment } \\
\text { of small hepatocellular carcinomas in } \\
\text { patients with cirrhosis. (New England } \\
\text { Journal of Medicine). }\end{array}$ & Research & 3,154 & $\begin{array}{l}\text { Department of Surgery, National } \\
\text { Cancer Institute, Milan, (Italy). }\end{array}$ \\
\hline 12 & & $\begin{array}{l}\text { Management of hepatocellular } \\
\text { carcinoma (Hepatology) }\end{array}$ & $\begin{array}{l}\text { Practice } \\
\text { guideline }\end{array}$ & 2,959 & $\begin{array}{l}\text { University of Barcelona, Institut } \\
\text { d'Investigacions Biomèdiques }\end{array}$ \\
\hline
\end{tabular}


Continued

\begin{tabular}{|c|c|c|c|c|c|}
\hline Rank $^{c}$ & $\begin{array}{l}\text { Author, Year } \\
\text { [Reference] }\end{array}$ & Title (Journal) & Category & $\begin{array}{l}\text { Number of } \\
\text { citations }\end{array}$ & $\begin{array}{l}\text { Origin: First author's } \\
\text { organisation, location (country) }\end{array}$ \\
\hline & $\begin{array}{l}\text { Bruix and } \\
\text { Sherman, } \\
2005^{25}\end{array}$ & & & & $\begin{array}{l}\text { August Pi i Sunyer, Barcelona, } \\
\text { (Spain). }\end{array}$ \\
\hline 13 & $\begin{array}{l}\text { Kuo et al, } \\
1989^{90}\end{array}$ & $\begin{array}{l}\text { An assay for circulating antibodies to } \\
\text { a major etiologic virus of human } \\
\text { non-A, non-B hepatitis. (Science). }\end{array}$ & Research & 2,951 & $\begin{array}{l}\text { Chiron Corporation, Emeryville, } \\
\text { California, (United States). }\end{array}$ \\
\hline 14 & $\begin{array}{l}\text { Ogura et al, } \\
2001^{91}\end{array}$ & $\begin{array}{l}\text { A frameshift mutation in NOD2 } \\
\text { associated with susceptibility to } \\
\text { Crohn's disease. (Nature). }\end{array}$ & Research & 2,917 & $\begin{array}{l}\text { The University of Michigan Medical } \\
\text { School, Ann Arbor, Michigan, } \\
\text { (United States). }\end{array}$ \\
\hline 15 & $\begin{array}{l}\text { Parsonnet et al, } \\
1991^{92}\end{array}$ & $\begin{array}{l}\text { Helicobacter pylori infection and the } \\
\text { risk of gastric carcinoma. (New } \\
\text { England Journal of Medicine). }\end{array}$ & Research & 2,913 & $\begin{array}{l}\text { Department of Medicine, Stanford } \\
\text { University School of Medicine, } \\
\text { California, (United States). }\end{array}$ \\
\hline 16 & $\begin{array}{l}\text { Knodell et al, } \\
1981^{26}\end{array}$ & $\begin{array}{l}\text { Formulation and application of a } \\
\text { numerical scoring system for } \\
\text { assessing histological activity in } \\
\text { asymptomatic chronic active hepatitis. } \\
\text { (Hepatology). }\end{array}$ & Research & 2,890 & $\begin{array}{l}\text { Gastroenterology Section, } \\
\text { Veterans Administration Medical } \\
\text { Center, Minneapolis, Minnesota, } \\
\text { (United States). }\end{array}$ \\
\hline 17 & $\begin{array}{l}\text { Dixon et al, } \\
1996^{93}\end{array}$ & $\begin{array}{l}\text { Classification and grading of gastritis. } \\
\text { The updated Sydney System. } \\
\text { International Workshop on the } \\
\text { Histopathology of Gastritis, Houston } \\
\text { 1994. (The American Journal of } \\
\text { Surgical Pathology). }\end{array}$ & Article & 2,874 & $\begin{array}{l}\text { University of Leeds, (United } \\
\text { Kingdom). }\end{array}$ \\
\hline 18 & $\begin{array}{l}\text { Burris et al, } \\
1997^{94}\end{array}$ & $\begin{array}{l}\text { Improvements in survival and clinical } \\
\text { benefit with gemcitabine as first-line } \\
\text { therapy for patients with advanced } \\
\text { pancreas cancer: a randomized trial. } \\
\text { (Journal of Clinical Oncology). }\end{array}$ & Research & 2,830 & $\begin{array}{l}\text { Institute for Drug Development, } \\
\text { Cancer Therapy and Research } \\
\text { Center, San Antonio, Texas, } \\
\text { (United States). }\end{array}$ \\
\hline 19 & $\begin{array}{l}\text { Cunningham } \\
\text { et al, } 2004^{95}\end{array}$ & $\begin{array}{l}\text { Cetuximab monotherapy and } \\
\text { cetuximab plus irinotecan in } \\
\text { irinotecan-refractory metastatic } \\
\text { colorectal cancer. (New England } \\
\text { Journal of Medicine). }\end{array}$ & Research & 2,772 & $\begin{array}{l}\text { Royal Marsden Hospital, London, } \\
\text { (United Kingdom). }\end{array}$ \\
\hline 20 & $\begin{array}{l}\text { Hayashi et al, } \\
2001^{96}\end{array}$ & $\begin{array}{l}\text { Complete genome sequence of } \\
\text { enterohemorrhagic Escherichia coli } \\
\text { O157:H7 and genomic comparison } \\
\text { with a laboratory strain K-12. (DNA } \\
\text { Research). }\end{array}$ & Research & 2,755 & $\begin{array}{l}\text { Department of Microbiology, } \\
\text { Miyazaki Medical College, } \\
\text { Kiyotake, (Japan). }\end{array}$ \\
\hline 21 & $\begin{array}{l}\text { Feder et al, } \\
1996^{97}\end{array}$ & $\begin{array}{l}\text { A novel MHC class I-like gene is } \\
\text { mutated in patients with hereditary } \\
\text { haemochromatosis. (Nature } \\
\text { Genetics). }\end{array}$ & Research & 2,744 & $\begin{array}{l}\text { Mercator Genetics, Inc., Menlo } \\
\text { Park, California, (United States) }\end{array}$ \\
\hline 22 & $\begin{array}{l}\text { McHutchison et } \\
\text { at, } 1998^{98}\end{array}$ & $\begin{array}{l}\text { Interferon alfa-2b alone or in } \\
\text { combination with ribavirin as initial } \\
\text { treatment for chronic hepatitis } \\
\text { C. Hepatitis Interventional Therapy } \\
\text { Group. (New England Journal of } \\
\text { Medicine). }\end{array}$ & Research & 2,639 & $\begin{array}{l}\text { Division of Gastroenterology- } \\
\text { Hepatology, Scripps Clinic and } \\
\text { Research Foundation, La Jolla, } \\
\text { California, (United States). }\end{array}$ \\
\hline 23 & $\begin{array}{l}\text { Groux et al, } \\
1997^{99}\end{array}$ & $\begin{array}{l}\text { A CD4+ T-cell subset inhibits } \\
\text { antigen-specific T-cell responses and } \\
\text { prevents colitis. (Nature) }\end{array}$ & Research & 2,627 & $\begin{array}{l}\text { DNAX Research Institute of } \\
\text { Molecular and Cellular Biology, } \\
\text { Inc., Human Immunology } \\
\text { Department, Palo Alto, California, } \\
\text { (United States). }\end{array}$ \\
\hline 24 & $\begin{array}{l}\text { Morin et al, } \\
1997^{100}\end{array}$ & $\begin{array}{l}\text { Activation of beta-catenin-Tcf } \\
\text { signaling in colon cancer by } \\
\text { mutations in beta-catenin or APC. } \\
\text { (Science) }\end{array}$ & Research & 2,613 & $\begin{array}{l}\text { Howard Hughes Medical Institute } \\
\text { and Johns Hopkins Oncology } \\
\text { Center, Baltimore, Maryland, } \\
\text { (United States). }\end{array}$ \\
\hline
\end{tabular}




\section{Continued}

\begin{tabular}{lll}
\hline Rank $^{\mathbf{c}}$ & $\begin{array}{l}\text { Author, Year } \\
\text { [Reference] }\end{array}$ & Title (Journal) \\
\hline 25 & $\begin{array}{l}\text { Ishak et al, } \\
1995^{27}\end{array}$ & $\begin{array}{l}\text { Histological grading and staging of } \\
\text { Chronic hepatitis. (Journal of } \\
\text { Hepatology). }\end{array}$ \\
26 & $\begin{array}{l}\text { Nataro and } \\
\text { Kaper, 1998 }\end{array}$ & $\begin{array}{l}\text { Diarrheagenic Escherichia coli. } \\
\text { (Clinical Microbiology Reviews). }\end{array}$
\end{tabular}

Boland et al, $1998^{102}$

Bruix et al, $2001^{28}$

\section{Llovet et al,
$2003^{103}$ \\ 29 Llovet et
$2003^{103}$}

Demetri et al, $2002^{104}$

Aaltonen et al, 1993. ${ }^{106}$

Bombardier et al, $2000^{107}$

Best et al, $1976^{29}$

Thiebaut et al, $1987^{108}$

Winawer et al, $1993^{105}$

36

Kleiner et al, $2005^{30}$

37

Fishel et al, $1993^{109}$
A National Cancer Institute Workshop on Microsatellite Instability for cancer detection and familial predisposition: development of international criteria for the determination of microsatellite instability in colorectal cancer.

(Cancer Research)

Clinical management of

hepatocellular carcinoma.

Conclusions of the Barcelona-2000

EASL conference. European

Association for the Study of the Liver ( Journal of Hepatology).

Hepatocellular carcinoma. (Lancet).

Review

2,401

Research

2,383

mesylate in advanced gastrointestinal stromal tumors. (New England Journal of Medicine).

Prevention of colorectal cancer by colonoscopic polypectomy. The National Polyp Study Workgroup. (New England Journal of Medicine).

Clues to the pathogenesis of familial colorectal cancer. (Science).

Comparison of upper gastrointestinal toxicity of rofecoxib and naproxen in patients with rheumatoid arthritis. VIGOR Study Group. (New England Journal of Medicine).

Development of a Crohn's disease activity index. National Cooperative Crohn's Disease Study (Gastroenterology)

Cellular localization of the multidrug-resistance gene product $P$ glycoprotein in normal human tissues (Proceedings of the National Academy of Sciences of the United States of America).

Design and validation of a histological Research 2,222 scoring system for nonalcoholic fatty liver disease. (Hepatology)

\section{The human mutator gene homolog}

Research

2,207

Research 2,355

Research 2,337

Research 2,315

Research 2,263

Research 2,245

hereditary nonpolyposis colon cancer. (Cell).

Number of Origin: First author's citations organisation, location (country)

Article 2,603 Armed Forces Institute of Pathology, Washington, (United States).

Department of Medicine, University of Maryland School of Medicine, Baltimore, (United States).

University of California, San Diego (United States).

Liver Unit, Digestive Disease Institute, Hospital Clinic, IDIBAPS, Barcelona, Catalonia, (Spain).

Laboratory of Molecular Biology, National Cancer Institute, Bethesda, MD, (United States).

Laboratory of Pathology, National Cancer Institute, Bethesda, MD, (United States)

Department of Microbiology and Molecular Genetics Markey Center for Molecular Genetics University of Vermont Medical School Burlington, (United States) 
Continued

\begin{tabular}{|c|c|c|c|c|c|}
\hline Rank $^{c}$ & $\begin{array}{l}\text { Author, Year } \\
\text { [Reference] }\end{array}$ & Title (Journal) & Category & $\begin{array}{l}\text { Number of } \\
\text { citations }\end{array}$ & $\begin{array}{l}\text { Origin: First author's } \\
\text { organisation, location (country) }\end{array}$ \\
\hline 38 & Angulo, $2002^{110}$ & $\begin{array}{l}\text { Nonalcoholic fatty liver disease. (New } \\
\text { England Journal of Medicine). }\end{array}$ & Review & 2,202 & $\begin{array}{l}\text { Division of Gastroenterology and } \\
\text { Hepatology, Mayo Clinic and } \\
\text { Foundation, Rochester, Minnesota, } \\
\text { (United States). }\end{array}$ \\
\hline 39 & $\begin{array}{l}\text { Targan et al, } \\
1997^{111}\end{array}$ & $\begin{array}{l}\text { A short-term study of chimeric } \\
\text { monoclonal antibody cA2 to tumor } \\
\text { necrosis factor alpha for Crohn's } \\
\text { disease. Crohn's Disease cA2 Study } \\
\text { Group. (New England Journal of } \\
\text { Medicine). }\end{array}$ & Research & 2,173 & $\begin{array}{l}\text { Cedars-Sinai Medical Center, Los } \\
\text { Angeles, California (United } \\
\text { States). }\end{array}$ \\
\hline 40 & $\begin{array}{l}\text { Stocker et al, } \\
1987^{112}\end{array}$ & $\begin{array}{l}\text { Bilirubin is an antioxidant of possible } \\
\text { physiological importance (Science). }\end{array}$ & Research & 2147 & $\begin{array}{l}\text { University of California, Berkeley, } \\
\text { Department of Biochemistry, } \\
\text { Berkeley, California (United } \\
\text { States). }\end{array}$ \\
\hline 41 & $\begin{array}{l}\text { Podolsky, } \\
2002^{113}\end{array}$ & $\begin{array}{l}\text { Inflammatory bowel disease. (New } \\
\text { England Journal of Medicine). }\end{array}$ & Review & 2,118 & $\begin{array}{l}\text { Gastrointestinal unit and the } \\
\text { Center for the Study of } \\
\text { Inflammatory Bowel Disease, } \\
\text { Massachusetts General Hospital } \\
\text { and Harvard Medical School, } \\
\text { Boston, (United States). }\end{array}$ \\
\hline 42 & $\begin{array}{l}\text { de Gramont } \\
\text { et al, } 2000^{114}\end{array}$ & $\begin{array}{l}\text { Leucovorin and fluorouracil with or } \\
\text { without oxaliplatin as first- line } \\
\text { treatment in advanced colorectal } \\
\text { cancer. (Journal of Clinical Oncology). }\end{array}$ & Research & 2,094 & $\begin{array}{l}\text { Service de Médecine } \\
\text { Interne-Oncologie, Hôpital } \\
\text { Saint-Antoine, Paris, (France). }\end{array}$ \\
\hline 43 & $\begin{array}{l}\text { Hadziyannis } \\
\text { et al, } 2004^{115}\end{array}$ & $\begin{array}{l}\text { Peginterferon-alpha2a and ribavirin } \\
\text { combination therapy in chronic } \\
\text { hepatitis C: a randomized study of } \\
\text { treatment duration and ribavirin dose. } \\
\text { (Annals of Internal Medicine) }\end{array}$ & Research & 2,063 & $\begin{array}{l}\text { Department of Medicine and } \\
\text { Hepatology, Henry Dunant } \\
\text { Hospital, Athens, (Greece). }\end{array}$ \\
\hline 44 & $\begin{array}{l}\text { Mandel et al, } \\
1993^{116}\end{array}$ & $\begin{array}{l}\text { Reducing mortality from colorectal } \\
\text { cancer by screening for fecal occult } \\
\text { blood. Minnesota Colon Cancer } \\
\text { Control Study. (New England Journal } \\
\text { of Medicine). }\end{array}$ & Research & 2,047 & $\begin{array}{l}\text { Division of Environmental and } \\
\text { Occupational Health, University of } \\
\text { Minnesota, Minneapolis, (United } \\
\text { States). }\end{array}$ \\
\hline 45 & $\begin{array}{l}\text { Saltz et al, } \\
2000^{117}\end{array}$ & $\begin{array}{l}\text { Irinotecan plus fluorouracil and } \\
\text { leucovorin for metastatic colorectal } \\
\text { cancer. Irinotecan Study Group. (New } \\
\text { England Journal of Medicine). }\end{array}$ & Research & 2,040 & $\begin{array}{l}\text { Memorial Sloan-Kettering Cancer } \\
\text { Center, New York, (united States). }\end{array}$ \\
\hline 46 & $\begin{array}{l}\text { Uemura et al, } \\
2001^{118}\end{array}$ & $\begin{array}{l}\text { Helicobacter pylori infection and the } \\
\text { development of gastric cancer. (New } \\
\text { England Journal of Medicine). }\end{array}$ & Research & 2,039 & $\begin{array}{l}\text { Department of Gastroenterology, } \\
\text { Kure Kyosai Hospital, Kure City, } \\
\text { (Japan) }\end{array}$ \\
\hline 47 & $\begin{array}{l}\text { Desmet et al, } \\
1994^{31}\end{array}$ & $\begin{array}{l}\text { Classification of chronic hepatitis: } \\
\text { diagnosis, grading and staging. } \\
\text { (Hepatology). }\end{array}$ & Review & 2038 & $\begin{array}{l}\text { Department of Pathology, Catholic } \\
\text { University of Leuven, (Belgium). }\end{array}$ \\
\hline 48 & $\begin{array}{l}\text { Beasley et al, } \\
1981^{119}\end{array}$ & $\begin{array}{l}\text { Hepatocellular carcinoma and } \\
\text { hepatitis B virus. A prospective study } \\
\text { of } 22707 \text { men in Taiwan. (Lancet). }\end{array}$ & Research & 2,029 & $\begin{array}{l}\text { University Washington Medical } \\
\text { Research Unit, Taipei, Taiwan. }\end{array}$ \\
\hline 49 & $\begin{array}{l}\text { El-Serag and } \\
\text { Rudolph, } \\
2007^{32}\end{array}$ & $\begin{array}{l}\text { Hepatocellular carcinoma: } \\
\text { epidemiology and molecular } \\
\text { carcinogenesis. (Gastroenterology). }\end{array}$ & Review & 2,028 & $\begin{array}{l}\text { Michael E. DeBakey Veterans } \\
\text { Administration Medical Center and } \\
\text { Baylor College of Medicine, } \\
\text { Houston, Texas, (United States) }\end{array}$ \\
\hline 50 & $\begin{array}{l}\text { Eberhart et al, } \\
1994^{33}\end{array}$ & $\begin{array}{l}\text { Up-regulation of cyclooxygenase } 2 \\
\text { gene expression in human colorectal } \\
\text { adenomas and adenocarcinomas. } \\
\text { (Gastroenterology) }\end{array}$ & Research & 1,929 & $\begin{array}{l}\text { Vanderbilt University Medical } \\
\text { Center, Nashville, Tennessee } \\
\text { (United States). }\end{array}$ \\
\hline
\end{tabular}

